\title{
Distinguishing Viruses Responsible for Influenza-Like Illness
}

\author{
Julie A. Spencer ${ }^{\mathrm{a}}$, Deborah P. Shutt ${ }^{\mathrm{a}}$, Sarah K. Moser ${ }^{\mathrm{b}}$, Hannah Clegg ${ }^{\mathrm{a}}$, \\ Helen J. Wearing ${ }^{\mathrm{c}, \mathrm{d}}$, Harshini Mukundan ${ }^{\mathrm{e}}$, Carrie A. Manore ${ }^{\mathrm{a}^{*}}$ \\ ${ }^{a}$ A-1 Information Systems and Modeling, Los Alamos National Laboratory, NM87545, USA \\ ${ }^{b}$ Bard College, Annandale-On-Hudson, NY12504, USA \\ ${ }^{c}$ Department of Biology, University of New Mexico, NM87102, USA \\ ${ }^{d}$ Department of Mathematics and Statistics, University of New Mexico, NM87102, USA \\ ${ }^{e}$ C-PCS Physical Chemistry and Applied Spectroscopy, Los Alamos National Laboratory, \\ NM87545, USA
}

\begin{abstract}
The many respiratory viruses that cause influenza-like illness (ILI) are reported and tracked as one entity, defined by the CDC as a group of symptoms that include a fever of 100 degrees Fahrenheit and a cough and/or a sore throat. In the United States alone, ILI impacts 9-49 million people every year. While tracking ILI as a single clinical syndrome is informative in many respects, the underlying viruses differ in their parameters and outbreak properties. Most existing models treat either a single respiratory virus or ILI as a whole. However, there is a need for models capable of comparing several individual ILI viruses. To address this need, here we present a flexible model and simulations of epidemics for influenza, RSV, rhinovirus, seasonal coronavirus, adenovirus, and SARS/MERS, parameterized by a systematic literature review and accompanied by a global sensitivity analysis. We find that for these biological causes of ILI, their parameter values, timing, prevalence, and proportional contributions differ substantially. These results demonstrate that distinguishing the viruses that cause influenza-like illness will be an important aspect of future work on ILI diagnostics, mitigation, modeling, and preparation for future unknown pandemics.
\end{abstract}

\footnotetext{
${ }^{*}$ Corresponding author at: Mail Stop F608, TA-03,

Los Alamos National Laboratory, NM87545, USA

Email address: cmanore@lanl.gov (Carrie A. Manore)
} 
Keywords: respiratory pathogen, diagnostics, deterministic model, epidemiological parameter, pandemic preparedness

\section{Introduction}

Emerging infectious diseases are a major threat to global health security, as exemplified by the recent COVID-19 pandemic. The ease of transmissibility makes respiratory pathogens especially suited for epidemic spread [1]. Viral res5 piratory infections account for a large burden of annual morbidity and mortality worldwide 2] and are the cause more than 400,000 hospitalizations in children less than 18 years old [3] in the United States every year, demonstrating the perpetual scale of the challenge.

Most of these viral infections are categorized as Influenza-like Illnesses (ILI), which are defined as cases of possible influenza, or other illnesses resulting in a set of symptoms that are indistinguishable from those attributed to influenza viruses [4]. The CDC characterizes ILI as infections presenting with a fever of $100^{\circ} \mathrm{F}$, and a cough and/or a sore throat [5], although common symptoms attributed to ILI include fever, chills, malaise, dry cough, loss of appetite, body aches, and nausea, combinations of which manifest depending on various pathogen-specific, environment specific, and host-determined factors [6].

The number of people impacted by ILI in the USA and beyond is significant every single year, notwithstanding the COVID pandemic. ILINet, which consists of outpatient healthcare providers in all 50 states, Puerto Rico, the District of Columbia and the U.S. Virgin Islands, reports over 60 million patient visits during the 2018-19 season [7, 8. Indeed, $8 \%$ of the US population is considered to be infected with symptomatic influenza-like illness every year [9].

Defining ILI as a syndromic cluster rather than a specific disease or diseases is informative for keeping track of syndromic case counts, as well as for important analysis and forecasting [10. However, the cluster of symptoms known as ILI is caused by many underlying pathogens [11, 12, most commonly, influenza viruses, common cold viruses, such as rhinovirus, adenovirus, human 
respiratory syncytial virus (RSV), parainfluenza virus (PIV), human metapneumovirus (hMPV) [13, and human coronaviruses (HCoV), a novel variant of which is responsible for the COVID-19 pandemic 14 .

Despite the multifaceted biological etiology of ILI, diagnostic testing for specific viruses underlying ILI is relatively rare [5], and many of the diagnostic outcomes are based on syndromic evaluation at the point of care. There are no tailored discriminatory diagnostics for use at the point of care, to evaluate pathogens that impact 9-49 million people every year in the United States alone [5]. This creates a knowledge gap in which an emergent novel respiratory pathogen such as COVID-19 can go undetected [15]. An increased understanding of the biological dynamics of specific pathogens causing ILI is needed to prevent unnecessary suffering and death [16, 17, 18.

Although clinical studies have been conducted to assess the contribution of different viruses to ILI [19, 12, 20, 21, 22, 23, the reliance on syndromic diagnostics and the consequent impact on identification and of novel threats has not been assessed until recently 24. Modeling studies that explore the mechanism of transmission and spread of ILI pathogens have also been conducted [25]. A recent study has shown that aggregrating the underlying ILI viruses separately rather than considering ILI as a single pathogen can improve ILI forecasts [24]. However, modeling studies using diagnostics measurements, and aimed at gaining insight into differing epidemic properties of the viruses underlying ILI, have been less abundant [26, 27].

To address the need for a flexible, abstract system that enables comparison of several ILI viruses in one paper, here we provide a deterministic model for five of the most common viral pathogens responsible for ILI. Our aim is to explore how pathogens with similar syndromes (and hence grouped together as ILI), can present with varied outbreak properties, thereby requiring varied interventions. We chose the pathogens on the basis of available literature, and the outcomes of a parallel clinical study conducted in Northern New Mexico - Influenza (A and B), Respiratory Syncytial Virus (RSV), rhinovirus, Human Coronavirus $(\mathrm{HCoV})$, and Adenovirus. We parameterized the model by conducting a sys- 
tematic literature review, and aligned the associated sensitivity analysis with

60

\section{Methods}

2.1. Model Structure

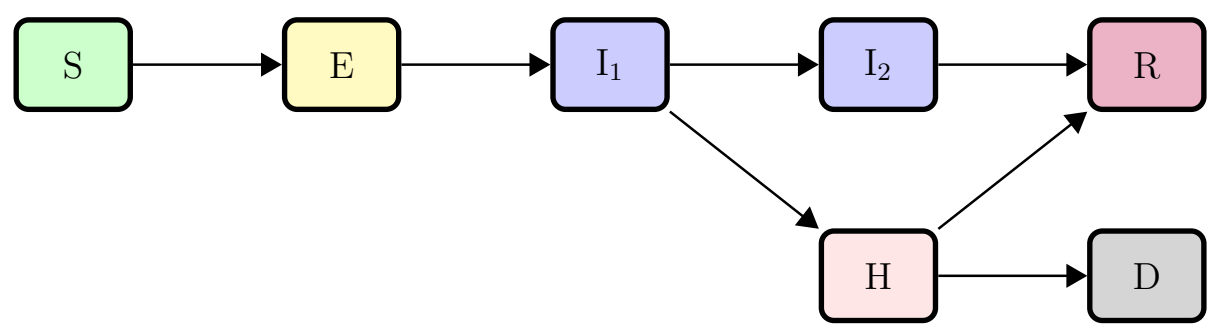

Figure 1: Transfer diagram for ILI virus transmission 


\begin{tabular}{ll}
\hline Variable & Description \\
\hline$S$ & Number of susceptible individuals \\
$E$ & Number of exposed (not infectious) individuals \\
$I_{1}$ & Number of initially infectious individuals \\
$I_{2}$ & Number of infected, non-hospitalized individuals \\
$H$ & Number of hospitalized individuals \\
$R$ & Number of recovered individuals \\
$D$ & Number of deceased individuals \\
\hline
\end{tabular}

Table 1: Descriptions of state variables

\begin{tabular}{|c|c|c|}
\hline Parameter & Description & Dimension \\
\hline$\beta$ & basic transmission rate & $\begin{array}{l}\text { individuals }^{-1} \times \\
\text { time }^{-1}\end{array}$ \\
\hline$c$ & reduction of transmission in hospital & dimensionless \\
\hline$\gamma_{1}$ & $\begin{array}{l}\text { per capita rate of progress from exposed to infec- } \\
\text { tious state }\end{array}$ & time $e^{-1}$ \\
\hline$\gamma_{2}$ & $\begin{array}{l}\text { per capita rate of progress through initial infec- } \\
\text { tious state }\end{array}$ & $t_{i m e} e^{-1}$ \\
\hline$\gamma_{3}$ & $\begin{array}{l}\text { per capita rate of progress through hospitalized } \\
\text { state }\end{array}$ & time $e^{-1}$ \\
\hline$\gamma_{4}$ & $\begin{array}{l}\text { per capita rate of progress through non- } \\
\text { hospitalized infectious state }\end{array}$ & time $e^{-1}$ \\
\hline$p_{1}$ & $\begin{array}{l}\text { proportion of initially infectious population that } \\
\text { becomes hospitalized }\end{array}$ & dimensionless \\
\hline$p_{2}$ & proportion of hospitalized population that die & dimensionless \\
\hline
\end{tabular}

Table 2: Parameter descriptions and dimensions 
The equations governing this model of common upper respiratory virus dynamics are given by

$$
\begin{aligned}
\frac{d S}{d t} & =-\beta S\left(I_{1}+I_{2}+c H\right) \\
\frac{d E}{d t} & =\beta S\left(I_{1}+I_{2}+c H\right)-\gamma_{1} E \\
\frac{d I_{1}}{d t} & =\gamma_{1} E-\gamma_{2} I_{1} \\
\frac{d I_{2}}{d t} & =\gamma_{2}\left(1-p_{1}\right) I_{1}-\gamma_{4} I_{2} \\
\frac{d H}{d t} & =\gamma_{2} p_{1} I_{1}-\gamma_{3} H \\
\frac{d R}{d t} & =\gamma_{4} I_{2}+\gamma_{3}\left(1-p_{2}\right) H \\
\frac{d D}{d t} & =\gamma_{3} p_{2} H
\end{aligned}
$$

The total population is $\mathrm{N}=\mathrm{S}+\mathrm{E}+\mathrm{I}_{1}+\mathrm{I}_{2}+\mathrm{H}+\mathrm{R}+\mathrm{D}$.

The total population $(\mathrm{N})$ consists of seven classes: susceptible $(\mathrm{S})$, exposed but not infectious (E), first infectious class $\left(\mathrm{I}_{1}\right)$, second (non-hospitalized) infectious class $\left(\mathrm{I}_{2}\right)$, hospitalized $(\mathrm{H})$, recovered $(\mathrm{R})$, or deceased (D) (Table 1). Individuals are considered susceptible until they contact an infectious individual ${ }_{85}$ from $\left(\mathrm{I}_{1}\right),\left(\mathrm{I}_{2}\right)$, or $(\mathrm{H})$. 
We modeled the progression of disease as follows: Given contact with an infectious individual, transmission takes place with some probability. After transmission has occurred, susceptible people move to the exposed class (E), where they spend a number of days equal to the period between infection and the onset of infectiousness (the latent period). In accordance with accepted literature, we assume that the latent period equals the incubation period, which is the period of time between exposure to the virus and the onset of symptoms.

After the latent period, individuals move to the first infectious class, $\left(\mathrm{I}_{1}\right)$. The duration of the first infectious period differs according to the underlying virus. Symptoms worsen for some proportion of individuals in the first infectious class, who then require hospitalization $(\mathrm{H})$, where they remain infectious, with reduced transmission $c$. From the hospital, individuals either recover (R) or die (D). Individuals who remain sick, but do not require hospitalization for the duration of the second infectious period $\left(\mathrm{I}_{2}\right)$, typically do not suffer from serious manifestations of the disease, and we assume that they recover entirely. We assume that hospitalized individuals have $25 \%$ less contact with susceptible individuals than do infectious people outside the hospital, which results in $25 \%$ less transmission during hospitalization. We further assume that all recovered individuals (R) gain full immunity to the virus causing the illness.

We assume that the total infected population $\left(\mathrm{T}=\mathrm{E}+\mathrm{I}_{1}+\mathrm{I}_{2}+\mathrm{H}\right)$ and the total infectious population ( $\mathrm{TI}=\mathrm{I}_{1}+\mathrm{I}_{2}+\mathrm{H}$ ) are homogeneously mixed. We assume that in the duration of a single year, demographics (natural birth or death) are negligible, and they are not modeled. We assume that the viruses act independently, although coinfection is not ruled out. Each epidemic begins with a single infected individual, and we calculate the transmission rate $\beta$ for each virus is by solving for $\beta$ in the expression for $R_{0}$ in Appendix $\mathrm{B}$, using the mean $R_{0}$ values for each virus from the literature.

\subsection{Model Parameterization}

To parameterize the model, we reviewed the literature for epidemiological measurements of incubation period, infectious period, hospitalization period, 
hospitalized proportion, case fatality proportion, and $R_{0}$ (cf. Table 2 for influenza A and B, RSV, rhinoviruses, coronaviruses, and adenoviruses. We included results from experimental and observational studies, as well as from systematic reviews. We also included estimates of $R_{0}$ from modeling studies, for even when symptomatically similar, many viral pathogens vary in their reproductive number. In the case of SARS, we included an estimate for the infectious period, since values were lacking in the literature [28]. We searched Google Scholar for each virus, using the name of the virus, a description of the parameter, and the type of study. For example, "influenza AND incubation period AND experimental" yielded a list of papers reporting the results of experimental studies to determine incubation period of influenza virus infections in humans. We then read the top 10 cited papers, examined the details of each study, and recorded the results (Table 3).

We iterated this process for each pathogen, until either no additional studies could be found, or the information garnered had already been incorporated in our assessment. We consulted modeling and review studies only when experimental and observational studies were not available for a given pathogen. We obtained from two to nine values for each parameter, with the exceptions of $R_{0}$ for Adenoviruses, and the hospitalization period for SARS and MERS, for which we found only one value each. We calculated the mean and standard deviation of each parameter (Table 3).

SARS-CoV-2, the virus that causes COVID-19, is a member of genus Betacoronavirus, along with SARS-CoV and MERS-CoV [29]. Our parameter review includes values for strains 229E, NL63, OC43, HKU1, SARS-CoV, and MERS$\mathrm{CoV}$, the six commonly circulating strains of Coronaviruses that existed prior to the advent of COVID-19. We generated a separate Coronavirus parameter table, focused on comparing the parameter values of the seasonal strains to those of the more recent SARS-CoV and MERS-CoV (Table 4). We collected means when possible; and when means were not available, we recorded medians. 


\subsection{Global Sensitivity Analysis}

To prioritize the impact of parameters on model outputs for this nonlinear system, we carried out a global sensitivity analysis. We bounded the parameter space with the minimum and maximum parameters from the literature (Tables 3. 4. Appendix C.4). We simulated epidemics of five common upper respiratory viruses implicated in ILI: influenza, respiratory syncytial virus (RSV), Rhinovirus, seasonal human coronavirus $(\mathrm{HCoV})$, and adenovirus, alongside outbreak strains of SARS-CoV and MERS-CoV, grouped together.

We assessed the impact of five model input variables of $\beta$ (basic transmission rate), $\gamma_{1}$ (1/incubation period), $\gamma_{2}$ (1/onset to hospitalization), $\gamma_{3}$ (1/hospitalized period), and $\gamma_{4}(1 /$ non-hospitalized period $)$ on three response variables of total number of infections, magnitude of epidemic peak (peak height), and time to epidemic peak. We used Latin Hypercube Sampling (LHS) [30] to generate 10,000 sets of values from the total parameter space for each of the five parameters, for each of the viruses. We considered the parameter ranges for seasonal coronaviruses (HCoV) separately from SARS-CoV/MERS-CoV. We calculated $\beta$ ranges by solving Equation B.4 for $\beta$ and substituting the minimum and maximum values from the literature (Table D.5). In the case of adenovirus, we found only one $R_{0}$ value in the literature, and assumed minimum and maximum values of $-20 \%$ and $+20 \%$ from this single value. We solved the ODE system numerically for these sample input values using the default integration routine "ode" in R package deSolve, then constructed a dataframe of the marginal relations between the individual parameters and outputs. We generated sensitivity plots in R using Smoothed Conditional Means ("statsmooth") and trend lines using weighted least squares method Local Polynomial Regression Fitting in $\mathrm{R}$ ("loess") 31. We assumed a uniform distribution on the parameters.

\section{Results}

\subsection{Model Simulation Results}


A Five common seasonal ILI viruses during a simulated year

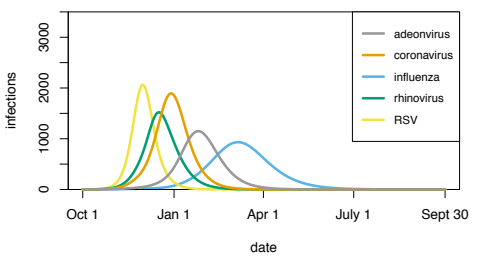

B Proportion of infections contributed by each virus

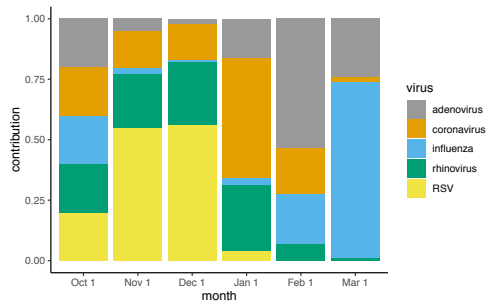

C Five common seasonal ILI viruses during a simulated year, with SARS/MERS-type outbreak

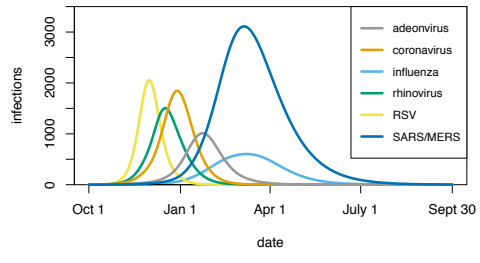

D Proportion of infections contributed by each virus, with SARS/MERS-type outbreak

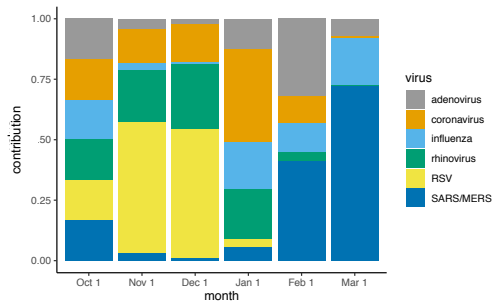

Figure 2: Seasonal and outbreak simulations. Panel 2A displays a numerical simulation of daily infections for five seasonal ILI viruses for one hypothetical year. The $\mathrm{x}$-axis shows time in days; the y-axis shows number of infections. Each virus begins by infecting one individual, with 9,999 susceptible individuals. We assume no background immunity, vaccination, or mitigations; each virus acts independently; probable coinfections are subtracted. Inputted parameter values are the means from the literature (Table 33. Values for coronavirus are the means for the pre-SARS-CoV-2, endemic, seasonal coronaviruses OC43, 229E, HKU1, and NL63, considered as a group. Panel 2B displays six snapshots of the proportion contributed by each virus on the first day of each month of the hypothetical "flu" season. The x-axis shows the first day of each month; the y-axis shows the proportional contributions. Panels $2 \mathrm{C}$ and $2 \mathrm{D}$ are the analogous plots, with the inclusion of the outbreak coronaviruses SARS-CoV and MERS-CoV, considered as a group. 
We find that when we numerically simulate seasonal epidemics for five common ILI viruses, setting all of their starting times at October 1st, the varied ranges of historic parameter values for each virus result in varied timing, prevalence, and contributions of these underlying biological causes of ILI (Figure 2). RSV peaks in December, followed by rhinovirus. Seasonal coronavirus peaks in January, adenovirus peaks in February, and influenza peaks in March. RSV has the greatest total cumulative infections and the highest peak (greatest maximum daily number of infections), while influenza has the least total cumulative infections and the lowest peak. The numerical simulation of SARS and MERS, not illustrated here as an epidemic curve because not considered seasonal, has the greatest overall number of cumulative infections.

We find that on the first day of any given month during the simulated ILI season, the composition of ILI attributable to the individual viruses varies considerably (see the stacked bar chart in (Figure 2)). On October 1st, each represents $20 \%$ of the total five infections, reflecting the initial condition that each epidemic begins with one infection. On November 1st and December 1st respectively, RSV constitutes $55 \%$ and $56 \%$ of total ILI infections. On January 1st, seasonal coronavirus contributes $50 \%$ of the total; on February 1st, adenovirus contributes 54\%; on March 1st, influenza contributes $73 \%$.

\subsection{Model Parameterization Results}

We find 104 studies that contained relevant parameter values (Table 3). According to our literature review, adenovirus exhibits the longest mean incubation period, seasonal coronavirus has the longest total mean infection period, and RSV has the highest mean $R_{0}$. Notably, out of the viruses studied, RSV incubation period values have the least standard deviation, while adenovirus values have the greatest standard deviation. Rhinovirus infectious period values have the least standard deviation, while SARS/MERS has the greatest. And finally, rhinovirus $R_{0}$ values have the least variation, while RSV $R_{0}$ values have the greatest variation. 
We find that the seasonal and historical outbreak coronaviruses differ considerably in their defining epidemiological parameters. The incubation and hospitalization periods of SARS and MERS are almost double that of their seasonal counterparts, while their infectious period is more than double. The mean $R_{0}$ for the betacoronaviruses SARS and MERS is 3.81, while that of the seasonal coronavirus strains is 2.84 (Table 4).

Of the 104 studies, 10 provide values for the percentage of each of the five viruses in question identified among ILI patients. In these 10 studies, on average, at least one virus is identified in $62 \%$ of individuals with ILI symptoms. Out of these $62 \%$ (mean values), influenza is identified in a $21.3 \%$ of samples, RSV in $13.5 \%$, rhinovirus in $22.6 \%$, human coronavirus in $8.8 \%$, and adenovirus in $8.1 \%$. The presence or absence of co-infection is not taken into account in the percentages reported by these studies. 


\begin{tabular}{|c|c|c|c|c|}
\hline Virus & $\begin{array}{c}\text { Range } \\
\text { (Min to Max) }\end{array}$ & Mean & $\begin{array}{l}\text { Standard } \\
\text { Deviation }\end{array}$ & References \\
\hline \multicolumn{5}{|c|}{ Incubation Period (days) } \\
\hline Influenza & $1-6.3$ & 2.61 & 0.993 & $32,33,34,35,36,37,38,39,40$ \\
\hline RSV & $3-8$ & 4.5 & 0.894 & 39, 32, 41, 42, 43, 40. \\
\hline Rhinovirus & $0.42-5.5$ & 2.36 & 1.10 & 39, 44, 45, 46, 47, 48, 49, 32, 43, 40 \\
\hline Human coronavirus & $1.9-14.7$ & 5.07 & 2.21 & $59,50,43,40,51,52,53,54$ \\
\hline Adenovirus & $1-30$ & 6.71 & 2.04 & 55, 39, 56, 57, 58, 40, 59. \\
\hline \multicolumn{5}{|c|}{ Infectious Period (days) } \\
\hline Influenza & $1-9$ & 4.58 & 2.56 & 33, 34, 37, 22, 60, 11 \\
\hline RSV & $1-21$ & 7.72 & 1.94 & 61, 62, 63, 11 \\
\hline Rhinovirus & $7-16$ & 9.40 & 1.70 & $11,64,65,66,67$ \\
\hline Human coronavirus & $7-35$ & 15.20 & 10.30 & {$[1,68,69,51,54,28$} \\
\hline Adenovirus & $7-17$ & 8.20 & 2.89 & [55, 11, 70, 59] \\
\hline \multicolumn{5}{|c|}{ Hospitalization Period (days) } \\
\hline Influenza & $3.5-11.3$ & 6.36 & 3.27 & $22,71,72,11,73$ \\
\hline RSV & $2-17.5$ & 5.24 & 2.32 & 74, 75, 76, 11, 77, 73, \\
\hline Rhinovirus & $0.4-1.67$ & 1.19 & 0.87 & $11,78,79$ \\
\hline Human coronavirus & $1.5-11$ & 4.96 & 4.27 & 11, 69, 80, 81 \\
\hline Adenovirus & $3.12-7$ & 4.71 & 2.03 & [11, 77, 82 \\
\hline \multicolumn{5}{|c|}{ Hospitalization Proportion } \\
\hline Influenza & $0.000035-0.062$ & 0.0037 & 0.0075 & $83,73,84,85,11$ \\
\hline RSV & $0.00034-0.29$ & 0.021 & 0.0215 & 86, 87, 83, $73,88,11,62$ \\
\hline Rhinovirus & $0.0093-0.024$ & 0.0121 & 0.0108 & [11, 89, 90, \\
\hline Human coronavirus & $0.00224-0.52$ & 0.188 & 0.241 & $11,91,92,69$ \\
\hline Adenovirus & $0.014-0.95$ & 0.43 & 0.39 & $12,93,11,70$ \\
\hline \multicolumn{5}{|c|}{ Case Fatality Proportion } \\
\hline Influenza & $0.000106-0.0827$ & 0.0312 & 0.0415 & 94, 95, 96, 97, 98, \\
\hline RSV & $0.00031-0.165$ & 0.0464 & 0.0627 & 99, 74, 95, 100, 88, 101 \\
\hline Rhinovirus & $0-0.125$ & 0.0451 & 0.0694 & 64, 102, 103 \\
\hline Human coronavirus & $0-0.34$ & 0.147 & 0.146 & 104, 105, 91, 92, 101, 103 \\
\hline Adenovirus & $0.00075-0.166$ & 0.103 & 0.0694 & 12, 106, 107, 108, 109, 70, \\
\hline \multicolumn{5}{|l|}{$\mathbf{R}_{0}$} \\
\hline Influenza & $1.06-3.4$ & 1.68 & 0.871 & 110, 111, 112, 113, 114, 115, \\
\hline RSV & $1.2-9.1$ & 133.47 & 2.67 & 62, 116, 117, 118, 119, 120, 121 \\
\hline Rhinovirus & $1.2-2.6$ & 1.88 & 0.70 & $120,121,122$ \\
\hline Human coronavirus & $2.7-8$ & 4.18 & 2.26 & 123, 105, 124, 125, 101, 126, 127, 128, \\
\hline Adenovirus & 2.34 (one value) & 2.34 & NA & 26 \\
\hline
\end{tabular}

Table 3: ILI parameters from literature. Coronavirus refer to the six pre-SARS-CoV-2 strains. 


\begin{tabular}{|c|c|c|c|c|}
\hline Virus & $\begin{array}{c}\text { Range } \\
\text { (Min to Max) }\end{array}$ & Mean & $\begin{array}{l}\text { Standard } \\
\text { Deviation }\end{array}$ & References \\
\hline \multicolumn{5}{|c|}{ Incubation Period (days) } \\
\hline Seasonal coronaviruses & $3.3-4.0$ & 3.46 & 0.33 & $39,50,43,40,51$ \\
\hline SARS and MERS & $4.7-10$ & 6.68 & 1.86 & $52,53,54$ \\
\hline \multicolumn{5}{|c|}{ Infectious Period (days) } \\
\hline Seasonal coronaviruses & $10.1-13.46$ & 11.29 & 1.53 & [11, 68, 51 \\
\hline SARS and MERS & $23.5-35$ & 28.5 & 4.81 & {$[54,28$} \\
\hline \multicolumn{5}{|c|}{ Hospitalization Period (days) } \\
\hline Seasonal coronaviruses & $2-4.9$ & 3.68 & 1.22 & 69,80 \\
\hline SARS and MERS & $1.5-11$ & 6.25 & 4.75 & {$[11,81$} \\
\hline \multicolumn{5}{|c|}{ Hospitalization Proportion } \\
\hline Seasonal coronaviruses & $0.0022-0.52$ & 0.024 & 0.018 & {$[11,91,92,69$} \\
\hline SARS and MERS & 0.00046 & 0.045 & 0.045 & 129 \\
\hline \multicolumn{5}{|c|}{ Case Fatality Proportion } \\
\hline Seasonal coronaviruses & $0-0.053$ & 0.027 & 0.027 & 91, 103 \\
\hline SARS and MERS & $0.06-0.34$ & 0.18 & 0.10 & $104,105,92,101$ \\
\hline \multicolumn{5}{|l|}{$\mathbf{R}_{\mathbf{0}}$} \\
\hline Seasonal coronaviruses & $2.2-3.7$ & 2.84 & 0.57 & 101, 130 \\
\hline SARS and MERS & $2.7-8$ & 3.81 & 1.81 & 123, 105, 124, 125, 126, 127, 128, \\
\hline
\end{tabular}

Table 4: This table distinguishes between endemic seasonal coronaviruses (229E, NL63, OC43, and HKU1) and historic sporadic outbreak coronaviruses (SARS-CoV and MERS-CoV). 
The global sensitivity analysis for our nonlinear system reveals several differences between the six viruses under consideration: influenza, RSV, rhinovirus, seasonal coronavirus, adenovirus, and SARS/MERS.

The impact of the basic transmission rate $\beta$ on total cumulative infections is relatively tightly constrained for all six viruses Appendix E. The trend line for influenza is slightly sigmoid, while the trend lines appear exponential for the other five, approaching $100 \%$ of the population asymptotically near their mean $\beta$ values. For influenza and RSV, the Latin Hypercube Samples (LHS) for all five input variables have bimodal distributions for cumulative cases and time to peak. That is, for influenza and RSV, but not for the other four viruses, there are trivial numerical solutions for the system in which epidemics never take off, as well as nontrivial solutions, where they do take off. This is reflected in the disease-free equilibrium Appendix A and in the histograms Appendix E.

The impact of $\beta$ on peak height for the 10,000 LHS samples is not as constrained overall as for cumulative cases, although the variance is narrower than that of the other four input variables. The LHS sample distributions for output variable time to peak are bimodal for influenza and RSV, while they are unimodal for the other four viruses. Distributions for seasonal coronaviruses and historic outbreak coronaviruses (SARS/MERS) are unimodal Appendix E.

An important difference between the seasonal and outbreak coronaviruses may be seen in Figure 3. Note that the y-axis for the outbreak coronaviruses represents approximately double the time period of the $\mathrm{y}$-axis for seasonal coronaviruses. In both cases, the relationship of the transmission rate to the number of days to the epidemic peak is logarithmic and well constrained. In both cases, as the transmission rate increases, the time to peak shortens; conversely, as the transmission rate decreases, the time to peak is delayed. The other four input variables, representing speed of progression through the stages of disease, have unremarkable impacts on the output variables. 
medRxiv preprint doi: https://doi.org/10.1101/2020.02.04.20020404; this version posted April 23, 2021. The copyright holder for this preprint (which was not certified by peer review) is the author/funder, who has granted medRxiv a license to display the preprint in perpetuity.

It is made available under a CC-BY-NC 4.0 International license .

Global Sensitivity Results: Time to Peak
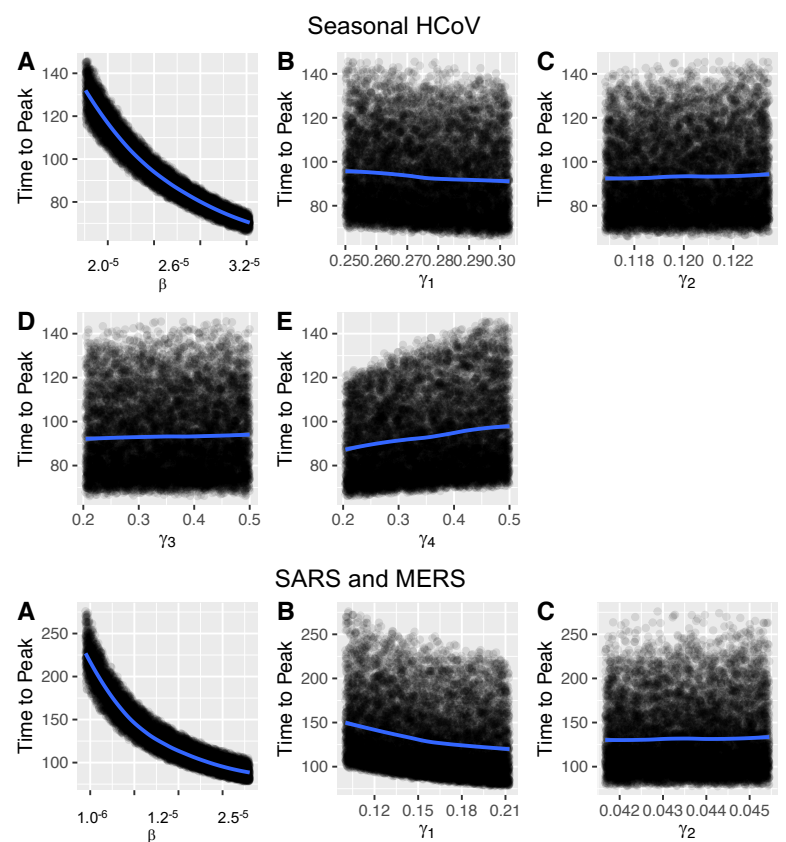

SARS and MERS
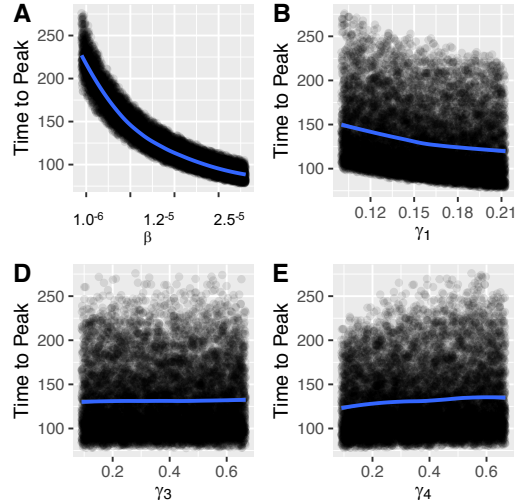

Figure 3: Global sensitivity analysis for seasonal coronaviruses (top) and historic outbreak coronaviruses SARS and MERS (bottom), showing the impact of five input variables on model output variable of time to epidemic peak. Note the different scale of the y axes on the $\beta$ plots. Complete sensitivity results may be found in Appendix E 


\section{Discussion}

Although the five viruses considered here present clinically with similar symptoms, their parameters and epidemic characteristics differ, illustrating the vast potential not only for misdiagnosis and uninformed mitigation strategies, but for missing early signals of future novel emerging diseases. These results support those in Pei and Shaman's recent paper 24 that demonstate differing outbreak properties of individual viruses that contribute to ILI.

From our sensitivity analysis, it is apparent that virus transmission rates, and therefore also effective reproduction numbers, have much greater impact on the output variables than do the other four input variables, more biologically intrinsic to each virus, that represent speed of the phases of disease progression. From a mitigation perspective, the transmission rate is the variable we can impact with public health policies. For example, by implementing mask-wearing and physical distancing, we can reduce and delay epidemic peak(s) of outbreak respiratory viruses, reducing cases and deaths as well as the burden on the healthcare system.

260 Many of the studies that generated parameter values evaluated populations treated at clinics or admitted at hospitals. However, a significant proportion of illness and death may occur outside of hospitals and clinics (see Cohen et al. 2017). Our formula for $R_{0}$ is based on the traditional assumption of a naive population; however, our parameter review reports many values from clinical 265 studies conducted on populations that have been exposed to the seasonal ILI viruses in circulation, and therefore have some level of background immunity. Thus, these values likely reflect the effective reproductive number $\left(R_{e}\right)$ rather than $R_{0}$, with the exception of SARS-CoV and MERS-CoV, which were novel zoonoses when they appeared. Further, the studies reviewed herein have taken place over many decades, during which viral evolution may be presumed to have occurred.

In our simulations, we treat the viruses contributing to the clinical syndrome 
of influenza-like illness as though they act independently, although a recent theoretical study has shown that even noninteracting pathogens are not necessarily mathematically independent [131]. A recent clinical study has shown rhinovirus can function to block subsequent infection by influenza [132]. Further studies are needed to assess the potential for both within-host and between-host viral interactions.

A limitation of our simulation results is that we have based them on mean historic parameter values, which does not take into account seasonal impacts on those parameters. Further, we have uniformly introduced the first infected individual for all viruses on October 1st of our hypothetical ILI season; however, in real world phenomena, these initial infections may happen at different times in different populations, and could happen in varied orders in different years.

The flexible deterministic model, numerical simulations, and sensitivity analysis included herein set the stage for future studies to investigate potential interactions of individual viruses that contribute to ILI. The parameterization study provides a meta-analysis of clinical studies during the past century that have provided the basic epidemiological parameters for modeling five of the common viruses contributing to the clinical syndrome of influenza-like illness. Along with previous work, the results presented herein indicate that in order to improve diagnosis, mitigation, and modeling of respiratory viruses, as well as to be prepared for the next pandemic, individual viruses contributing to influenza-like illness should be considered separately.

\section{CREdiT authorship contribution statement}

Julie A. Spencer: Conceptualization, Methodology, Formal analysis, Visualization, Writing - Original Draft, Writing - Review \& Editing. Deborah P. Shutt: Conceptualization, Methodology. Sarah K. Moser: Investigation, Visualization. Hannah Clegg: Conceptualization, Investigation. Helen J. Wearing: Conceptualization, Methodology, Formal analysis, Supervision, Writing - Review \& Editing. Harshini Mukundan: Conceptualization, Project administration, Funding acquisition, Supervision, Writing - Review \& 
Editing. Carrie A. Manore: Conceptualization, Methodology, Funding acquisition, Supervision, Writing - Review \& Editing.

\section{Declaration of Competing Interest}

The authors declare that they have no known competing financial interests or personal relationships that could have appeared to influence the work reported in this paper.

\section{Appendix A. Disease-free Equilibrium}

In the disease-free state, all infected classes are zero, that is, $E=I_{1}=I_{2}=$ $H=0$. Substituting and setting the derivatives equal to zero, it is evident that in the disease-free state, the other state variables $\mathrm{R}$ and $\mathrm{D}$ will continue to contain zero individuals, and that the Susceptible class $\mathrm{S}$ will remain equal to the total population $\mathrm{N}$.

If we set any one of $\mathrm{E}, \mathrm{I}_{1}, \mathrm{I}_{2}$, or $\mathrm{H}$ to zero, the other three state variables representing infected classes must also be zero. In this case, $\mathrm{N}=\mathrm{S}=10000$. Thus, where $x=\left(S, E, I_{1}, I_{2}, H, R, D\right)$ denotes solutions of the system, $x_{d f e}=$ $(10000,0,0,0,0,0,0)$ represents the disease-free equilibrium for the system.

\section{Appendix B. Derivation of Basic Reproductive Number}

The basic reproductive number $\left(R_{0}\right)$ is defined as the average number of secondary infections produced when one infected individual is introduced into a fully susceptible population. Four compartments, latently infected individuals (E), symptomatic and infected individuals $\left(\mathrm{I}_{1}\right)$, symptomatic and infected and non-hospitalized individuals $\left(\mathrm{I}_{2}\right)$, and hospitalized individuals $(\mathrm{H})$, together characterize the total infected population for the ILI virus system. To calculate $R_{0}$ for this system, we derive the next generation matrix [133]. 
Method:

1. Derive the matrix for the transmission term describing everyone entering (E): the "F" matrix;

2. Derive the matrix for the transition terms describing everyone transitioning between infected classes $\left(E, I_{1}, I_{2}, H\right)$ : the "V" matrix;

3. Next Generation Matrix $(\mathrm{NGM})=(F)\left(V^{-1}\right)$;

4. The largest dominant eigenvalue or spectral radius of the $\mathrm{NGM}=R_{0}$ for the system.

${ }_{340}$ The transmission term for the system is $\beta S\left(I_{1}+I_{2}+c H\right)$

$$
\mathbf{F}=\left(\begin{array}{cccc}
0 & \beta S & \beta S & \beta S c \\
0 & 0 & 0 & 0 \\
0 & 0 & 0 & 0 \\
0 & 0 & 0 & 0
\end{array}\right)
$$

The transition terms for the system are $\left(-\gamma_{1} E\right),\left(\gamma_{1} E-\gamma_{2} I_{1}\right),\left(\gamma_{2}\left(1-p_{1}\right) I_{1}-\right.$ $\left.{ }_{345} \gamma_{4} I_{2}\right),\left(\gamma_{2} p_{1} I_{1}-\gamma_{3} H\right)$.

$$
\mathbf{V}=\left(\begin{array}{cccc}
\gamma_{1} & 0 & 0 & 0 \\
-\gamma_{1} & \gamma_{2} & 0 & 0 \\
0 & -\gamma_{2}\left(1-p_{1}\right) & \gamma 4 & 0 \\
0 & -\gamma_{2} p_{1} & 0 & \gamma 3
\end{array}\right)
$$


The next generation matrix is thus

$$
\mathbf{F V}^{-1}=\left(\begin{array}{cccc}
\beta S\left(\frac{1}{\gamma_{2}}-\frac{\left(p_{1}-1\right)}{\gamma_{4}}+\frac{c p_{1}}{\gamma_{3}}\right) & \beta S\left(\frac{1}{\gamma_{2}}-\frac{\left(p_{1}-1\right)}{\gamma_{4}}+\frac{c p_{1}}{\gamma_{3}}\right) & \frac{\beta S}{\gamma_{4}} & \frac{\beta S c}{\gamma_{3}} \\
0 & 0 & 0 & 0 \\
0 & 0 & 0 & 0 \\
0 & 0 & 0 & 0
\end{array}\right)
$$

The spectral radius, or the largest positive eigenvalue of the next generation matrix, is the basic reproductive number of the system at the disease-free equilibrium.

$$
\mathbf{R}_{\mathbf{0}}=\frac{\beta S\left(c p_{1} \gamma_{2} \gamma_{4}-p_{1} \gamma_{2} \gamma_{3}+\gamma_{2} \gamma_{3}+\gamma_{3} \gamma_{4}\right)}{\gamma_{2} \gamma_{3} \gamma_{4}}
$$

$$
\mathbf{R}_{\mathbf{0}}=\beta S\left(\frac{1}{\gamma_{2}}+\frac{c p_{1}}{\gamma_{3}}+\frac{\left(1-p_{1}\right)}{\gamma_{4}}\right) e q: R 0_{2}
$$

This expression for the basic reproductive number $\left(R_{0}\right)$ depends on the parameters $\beta, c, p_{1}, \gamma_{2}, \gamma_{3}$ and $\gamma_{4}$, and on the initial conditions of the state variables. Equation B.5 shows that $R_{0}$ for this system is a combination of the transmission 
medRxiv preprint doi: https://doi.org/10.1101/2020.02.04.20020404; this version posted April 23, 2021. The copyright holder for this preprint (which was not certified by peer review) is the author/funder, who has granted medRxiv a license to display the preprint in perpetuity.

It is made available under a CC-BY-NC 4.0 International license .

that takes place in the pre-symptomatic $\left(I_{1}\right)$, symptomatic, $\left(I_{2}\right)$, and hospitalized $(\mathrm{H})$ compartments. This is the per-day transmission rate $(\beta)$ multiplied by the time spent in each of these compartments. 
medRxiv preprint doi: https://doi.org/10.1101/2020.02.04.20020404; this version posted April 23, 2021. The copyright holder for this preprint (which was not certified by peer review) is the author/funder, who has granted medRxiv a license to display the preprint in perpetuity.

It is made available under a CC-BY-NC 4.0 International license .

\section{Appendix C. Parameter Ranges}
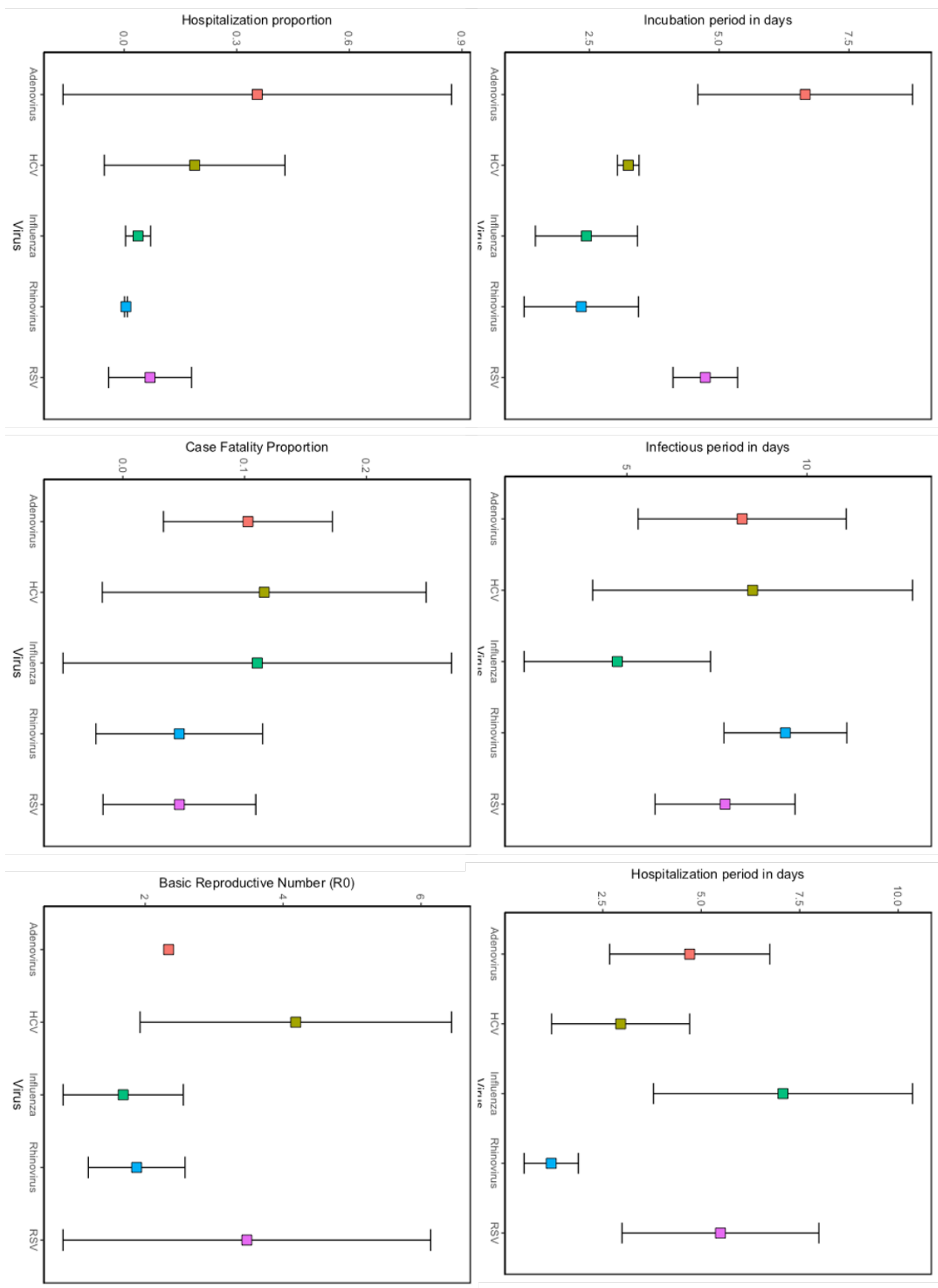

Figure C.4: Parameter ranges for five common ILI viruses from literature review 
medRxiv preprint doi: https://doi.org/10.1101/2020.02.04.20020404; this version posted April 23, 2021. The copyright holder for this preprint (which was not certified by peer review) is the author/funder, who has granted medRxiv a license to display the preprint in perpetuity.

\section{It is made available under a CC-BY-NC 4.0 International license}

\section{Appendix D. Transmission Rates}

\begin{tabular}{|l|c|c|c|}
\hline Virus & Min & Max & Mean \\
\hline Influenza & $9.69^{-6}$ & $3.12^{-5}$ & $1.54^{-5}$ \\
\hline RSV & $1.55^{-5}$ & $1.18^{-4}$ & $4.49^{-5}$ \\
\hline Rhinovirus & $1.81^{-5}$ & $3.92^{-5}$ & $2.83^{-5}$ \\
\hline Seasonal HCoV & $1.95^{-5}$ & $3.28^{-5}$ & $2.52^{-5}$ \\
\hline Adenovirus & $2.28^{-5}$ & $3.42^{-5}$ & $2.85^{-5}$ \\
\hline SARS/MERS & $9.47^{-6}$ & $2.81^{-5}$ & $1.34^{-5}$ \\
\hline
\end{tabular}

Table D.5: This table reports $\beta$ (basic transmission rate) values calculated from solving Equation (6) for $\beta$, and substituting in the parameter values from the literature review (Tables 3 and 4). 


\section{Appendix F. References}

\section{References}

[1] J. S. Kutter, M. I. Spronken, P. L. Fraaij, R. A. Fouchier, S. Herfst, Transmission routes of respiratory viruses among humans, Current opinion in virology 28 (2018) 142-151.

[2] A. D. Iuliano, K. M. Roguski, H. H. Chang, D. J. Muscatello, R. Palekar, S. Tempia, C. Cohen, J. M. Gran, D. Schanzer, B. J. Cowling, et al., Estimates of global seasonal influenza-associated respiratory mortality: a modelling study, The Lancet 391 (10127) (2018) 1285-1300.

[3] K. J. Henrickson, Advances in the laboratory diagnosis of viral respiratory disease, The Pediatric infectious disease journal 23 (1) (2004) S6-S10.

[4] A. Fowlkes, A. Giorgi, D. Erdman, J. Temte, K. Goodin, S. Di Lonardo, Y. Sun, K. Martin, M. Feist, R. Linz, R. Boulton, E. Bancroft, L. McHugh, J. Lojo, K. Filbert, L. Finelli, IISP Working Group, Viruses associated with acute respiratory infections and influenza-like illness among outpatients from the Influenza Incidence Surveillance Project, 2010-2011, J Infect Dis 209 (11) (2014) 1715-25. doi:10.1093/infdis/jit806.

[5] C. for Disease Control, P. (CDC), U.S. influenza surveillance system: Purpose and methods, FluView Website (downloaded October 29, 2020 2020) [cited $1 / 28 / 2020]$.

URL https://www.cdc.gov/flu/weekly/overview.htm

[6] B. Michiels, I. Thomas, P. Van Royen, S. Coenen, Clinical prediction rules combining signs, symptoms and epidemiological context to distinguish influenza from influenza-like illnesses in primary care: a cross sectional study, BMC family practice 12 (1) (2011) 4. 
[7] C. for Disease Control (CDC), National, regional, and state level outpatient illness and viral surveillance, https://gis.cdc.gov/grasp/fluview/fluportaldashboard.html (data downloaded on 10-28-2020 2020).

[8] J. D. Silverman, N. Hupert, A. D. Washburne, Using influenza surveillance networks to estimate state-specific prevalence of sars-cov-2 in the united states, Science translational medicine $12(554)$.

[9] J. I. Tokars, S. J. Olsen, C. Reed, Seasonal incidence of symptomatic influenza in the united states, Clinical Infectious Diseases 66 (10) (2018) $1511-1518$.

q [10] D. Osthus, K. R. Moran, Multiscale influenza forecasting (2019). arXiv: 1909.13766 URL https://arxiv.org/abs/1909.13766

[11] S. Taylor, P. Lopez, L. Weckx, C. Borja-Tabora, R. Ulloa-Gutierrez, E. Lazcano-Ponce, A. Kerdpanich, M. Angel Rodriguez Weber, A. Mascareñas de Los Santos, J.-C. Tinoco, M. A. P. Safadi, F. S. Lim, M. Hernandez-de Mezerville, I. Faingezicht, A. Cruz-Valdez, Y. Feng, P. Li, S. Durviaux, G. Haars, S. Roy-Ghanta, D. W. Vaughn, T. Nolan, Respiratory viruses and influenza-like illness: Epidemiology and outcomes in children aged 6 months to 10 years in a multi-country population sample, J Infect 74 (1) (2017) 29-41. doi:10.1016/j.jinf.2016.09.003.

[12] A. Galindo-Fraga, A. A. Ortiz-Hernández, A. Ramírez-Venegas, R. V. Vázquez, S. Moreno-Espinosa, B. Llamosas-Gallardo, S. Pérez-Patrigeon, M. Salinger, L. Freimanis, C.-y. Huang, W. Gu, M. L. Guerrero, J. Beigel, G. M. Ruiz-Palacios, La Red ILI 002 Study Group, Clinical characteristics and outcomes of influenza and other influenza-like illnesses in Mexico City, Int J Infect Dis 17 (7) (2013) e510-7. doi:10.1016/j.ijid.2013.01.006 L. Wei, Etiology and clinical characteristics of influenza-like illness (ili) 
in outpatients in beijing, june 2010 to may 2011, PloS one 7 (1) (2012) e28786.

[14] N. Chen, M. Zhou, X. Dong, J. Qu, F. Gong, Y. Han, Y. Qiu, J. Wang, Y. Liu, Y. Wei, et al., Epidemiological and clinical characteristics of 99 cases of 2019 novel coronavirus pneumonia in wuhan, china: a descriptive study, The Lancet 395 (10223) (2020) 507-513.

[15] S. Zayet, Q. Lepiller, H. Zahra, P.-Y. Royer, L. Toko, V. Gendrin, T. Klopfenstein, et al., Clinical features of covid-19 and influenza: a comparative study on nord franche-comte cluster, Microbes and infection.

[16] D. N. T. Nguyen, L. Q. Mai, J. E. Bryant, N. L. K. Hang, L. N. M. Hoa, B. Nadjm, P. Q. Thai, T. N. Duong, D. D. Anh, P. Horby, H. R. van Doorn, H. F. L. Wertheim, A. Fox, Epidemiology and etiology of influenzalike-illness in households in Vietnam; it's not all about the kids!, J Clin Virol 82 (2016) 126-132. doi:10.1016/j.jcv.2016.07.014.

[17] L. van Asten, C. van den Wijngaard, W. van Pelt, J. van de Kassteele, A. Meijer, W. van der Hoek, M. Kretzschmar, M. Koopmans, Mortality attributable to 9 common infections: significant effect of influenza A, respiratory syncytial virus, influenza $B$, norovirus, and parainfluenza in elderly persons, J Infect Dis 206 (5) (2012) 628-39. doi:10.1093/infdis/ jis415.

[18] K. A. Pawelek, C. Salmeron, S. Del Valle, Connecting within and betweenhosts dynamics in the influenza infection-staged epidemiological models with behavior change, J Coupled Syst Multiscale Dyn 3 (3) (2015) 233243. doi:10.1166/jcsmd.2015.1082.

[19] H. Li, Q. Wei, A. Tan, L. Wang, Epidemiological analysis of respiratory viral etiology for influenza-like illness during 2010 in zhuhai, china, Virology journal 10 (1) (2013) 143. 
[20] R. Gilca, R. Amini, M. Douville-Fradet, H. Charest, J. Dubuque, N. Boulianne, D. M. Skowronski, G. De Serres, Other respiratory viruses are important contributors to adult respiratory hospitalizations and mortality even during peak weeks of the influenza season, in: Open forum infectious diseases, Vol. 1, Oxford University Press, 2014.

[21] K. Bollaerts, J. Antoine, V. Van Casteren, G. Ducoffre, N. Hens, S. Quoilin, Contribution of respiratory pathogens to influenza-like illness consultations, Epidemiol Infect 141 (10) (2013) 2196-204. doi: 10.1017/S0950268812002506.

[22] M. Sansone, Å. Wiman, M. L. Karlberg, M. Brytting, L. Bohlin, L.-M. Andersson, J. Westin, R. Nordén, Molecular characterization of a nosocomial outbreak of influenza B virus in an acute care hospital setting, J Hosp Infect 101 (1) (2019) 30-37. doi:10.1016/j.jhin.2018.06.004.

[23] J. W. Rudge, N. Inthalaphone, R. Pavlicek, P. Paboriboune, B. Flaissier, C. Monidarin, N. Steenkeste, V. Davong, M. Vongsouvath, K. Bonath, et al., "epidemiology and aetiology of influenza-like illness among households in metropolitan vientiane, lao pdr": A prospective, communitybased cohort study, PloS one 14 (4).

[24] S. Pei, J. Shaman, Aggregating forecasts of multiple respiratory pathogens supports more accurate forecasting of influenza-like illness, PLoS computational biology 16 (10) (2020) e1008301.

[25] W. W. Thompson, L. Comanor, D. K. Shay, Epidemiology of seasonal influenza: use of surveillance data and statistical models to estimate the burden of disease, The Journal of infectious diseases 194 (Supplement_2) (2006) S82-S91.

[26] J. Reis, J. Shaman, Simulation of four respiratory viruses and inference of epidemiological parameters, Infectious Disease Modelling 3 (2018) 23-34. 
[27] L. Opatowski, M. Baguelin, R. M. Eggo, Influenza interaction with cocirculating pathogens and its impact on surveillance, pathogenesis, and epidemic profile: A key role for mathematical modelling, PLoS pathogens 14 (2) (2018) e1006770.

[29] R. Lu, X. Zhao, J. Li, P. Niu, B. Yang, H. Wu, W. Wang, H. Song,

[28] G. Chowell, C. Castillo-Chavez, P. W. Fenimore, C. M. Kribs-Zaleta, L. Arriola, J. M. Hyman, Model parameters and outbreak control for SARS, Emerg Infect Dis 10 (7) (2004) 1258-63. doi:10.3201/eid1007. 030647 .

B. Huang, N. Zhu, et al., Genomic characterisation and epidemiology of 2019 novel coronavirus: implications for virus origins and receptor binding, The Lancet 395 (10224) (2020) 565-574.

[ [30] M. D. McKay, R. J. Beckman, W. J. Conover, Comparison of three a methods for selecting values of input variables in the analysis of output from a computer code, Technometrics 21 (2) (1979) 239-245. doi: $10.1080 / 00401706.1979 .10489755$ URL http://dx.doi .org/10.1080/00401706.1979.10489755

[31] R. C. Team, et al., R: A language and environment for statistical computing.

[32] A. K. Zaas, M. Chen, J. Varkey, T. Veldman, A. O. Hero III, J. Lucas, Y. Huang, R. Turner, A. Gilbert, R. Lambkin-Williams, et al., Gene expression signatures diagnose influenza and other symptomatic respiratory viral infections in humans, Cell host \& microbe 6 (3) (2009) 207-217.

[33] R. S. Fritz, F. G. Hayden, D. P. Calfee, L. M. Cass, A. W. Peng, W. G. Alvord, W. Strober, S. E. Straus, Nasal cytokine and chemokine responses in experimental influenza A virus infection: results of a placebo-controlled trial of intravenous zanamivir treatment, J Infect Dis 180 (3) (1999) 58693. doi:10.1086/314938. 
[34] R. B. Couch, R. G. Douglas, Jr, D. S. Fedson, J. A. Kasel, Correlated studies of a recombinant influenza-virus vaccine. 3. protection against experimental influenza in man, J Infect Dis 124 (5) (1971) 473-80. doi:10.1093/infdis/124.5.473.

[35] A. F. Oner, A. Bay, S. Arslan, H. Akdeniz, H. A. Sahin, Y. Cesur, S. Epcacan, N. Yilmaz, I. Deger, B. Kizilyildiz, H. Karsen, M. Ceyhan, Avian influenza A (H5N1) infection in eastern Turkey in 2006, N Engl J Med 355 (21) (2006) 2179-85. doi:10.1056/NEJMoa060601.

[36] M. R. Moser, T. R. Bender, H. S. Margolis, G. R. Noble, A. P. Kendal, D. G. Ritter, An outbreak of influenza aboard a commercial airliner, Am J Epidemiol 110 (1) (1979) 1-6. doi:10.1093/oxfordjournals.aje. a112781.

[37] L. Kaiser, M. S. Briones, F. G. Hayden, Performance of virus isolation and directigen flu A to detect influenza A virus in experimental human infection, J Clin Virol 14 (3) (1999) 191-7. doi:10.1016/s1386-6532(99) $00058-\mathrm{x}$

[38] S. Kondo, K. Abe, The effects of influenza virus infection on FEV1 in asthmatic children. the time-course study, Chest 100 (5) (1991) 1235-8. doi: $10.1378 /$ chest.100.5.1235

[39] J. Lessler, N. G. Reich, R. Brookmeyer, T. M. Perl, K. E. Nelson, D. A. T. Cummings, Incubation periods of acute respiratory viral infections: a systematic review, Lancet Infect Dis 9 (5) (2009) 291-300. doi:10.1016/S1473-3099(09)70069-6.

[40] D. Wat, The common cold: a review of the literature, Eur J Intern Med 15 (2) (2004) 79-88. doi:10.1016/j.ejim.2004.01.006.

[41] K. M. Johnson, R. M. Chanock, D. Rifkind, H. M. Kravetz, V. Knight, Respiratory syncytial virus. IV. correlation of virus shedding, serologic response, and illness in adult volunteers, JAMA 176 (1961) 663-7. 
[42] C. R. Pringle, A. H. Filipiuk, B. S. Robinson, P. J. Watt, P. Higgins, D. A. Tyrrell, Immunogenicity and pathogenicity of a triple temperaturesensitive modified respiratory syncytial virus in adult volunteers, Vaccine 11 (4) (1993) 473-8. doi:10.1016/0264-410x(93)90290-e.

[43] D. Tyrrell, S. Cohen, J. Schilarb, Signs and symptoms in common colds, Epidemiology \& Infection 111 (1) (1993) 143-156.

[44] N. G. Reich, T. M. Perl, D. A. T. Cummings, J. Lessler, Visualizing clinical evidence: citation networks for the incubation periods of respiratory viral infections, PLoS One 6 (4) (2011) e19496. doi:10.1371/journal.pone. 0019496.

[45] R. G. Douglas, Jr, R. D. Rossen, W. T. Butler, R. B. Couch, Rhinovirus neutralizing antibody in tears, parotid saliva, nasal secretions and serum, J Immunol 99 (2) (1967) 297-303.

[46] P. C. Avila, J. A. Abisheganaden, H. Wong, J. Liu, S. Yagi, D. Schnurr, J. L. Kishiyama, H. A. Boushey, Effects of allergic inflammation of the nasal mucosa on the severity of rhinovirus 16 cold, J Allergy Clin Immunol 105 (5) (2000) 923-32. doi:10.1067/mai.2000.106214.

[47] C. L. Drake, T. A. Roehrs, H. Royer, G. Koshorek, R. B. Turner, T. Roth, Effects of an experimentally induced rhinovirus cold on sleep, performance, and daytime alertness, Physiol Behav 71 (1-2) (2000) 75-81. doi:10.1016/s0031-9384(00)00322-x.

[48] R. M. Naclerio, D. Proud, L. M. Lichtenstein, A. Kagey-Sobotka, J. O. Hendley, J. Sorrentino, J. M. Gwaltney, Kinins are generated during experimental rhinovirus colds, J Infect Dis 157 (1) (1988) 133-42. doi: 10.1093/infdis/157.1.133.

[49] J. M. Harris, J. M. Gwaltney Jr, Incubation periods of experimental rhinovirus infection and illness, Clinical infectious diseases 23 (6) (1996) $1287-1290$. 
[51] M. Valtonen, M. Waris, T. Vuorinen, E. Eerola, A. J. Hakanen, K. Mjosund, W. Grönroos, O. J. Heinonen, O. Ruuskanen, Common cold in Team

[52] A. Assiri, J. A. Al-Tawfiq, A. A. Al-Rabeeah, F. A. Al-Rabiah, S. Al-

[53] V. Virlogeux, M. Park, J. T. Wu, B. J. Cowling, Association between severity of MERS-CoV infection and incubation period, Emerg Infect Dis 22 (3) (2016) 526-8. doi:10.3201/eid2203.151437.

[54] R. M. Anderson, C. Fraser, A. C. Ghani, C. A. Donnelly, S. Riley, N. M. Ferguson, G. M. Leung, T. H. Lam, A. J. Hedley, Epidemiology, transmission dynamics and control of sars: the 2002-2003 epidemic, Philosophical Transactions of the Royal Society of London. Series B: Biological Sciences 359 (1447) (2004) 1091-1105.

[55] J. M. Sendra-Gutiérrez, D. Martín-Rios, I. Casas, P. Sáez, A. Tovar, C. Moreno, An outbreak of adenovirus type 8 keratoconjunctivitis in a nursing home in Madrid, Euro Surveill 9 (3) (2004) 27-30. doi: 10.2807/esm.09.03.00453-en. 
[56] D. R. Feikin, J. F. Moroney, D. F. Talkington, W. L. Thacker, J. E. Code, L. A. Schwartz, D. D. Erdman, J. C. Butler, M. S. Cetron, An outbreak of acute respiratory disease caused by Mycoplasma pneumoniae and adenovirus at a federal service training academy: new implications from an old scenario, Clin Infect Dis 29 (6) (1999) 1545-50. doi:10.1086/ 313500 .

[57] S. Berger, Infectious Diseases of Bhutan, O'Reilly Media, Inc., 2010.

[58] R. R. Tanz, Sore throat, in: R. Kliegman, P. Lye, B. Bordini, H. Toth, D. Basel (Eds.), Nelson Pediatric Symptom-Based Diagnosis E-Book, Elsevier Health Sciences, 2017.

URL https://books .google.com/books?id=0wRODgAAQBAJ

[59] C. Robinson, M. Echavarria, Adenoviruses, in: P. Murray, E. Baron, J. Jorgensen, M. Landry, M. Pfaller (Eds.), Manual of clinical microbiology, 9th Edition, Washington, DC, 2007, p. 1589.

[60] B. J. Cowling, V. J. Fang, S. Riley, J. S. Malik Peiris, G. M. Leung, Estimation of the serial interval of influenza, Epidemiology 20 (3) (2009) 344-7. doi:10.1097/EDE.0b013e31819d1092.

[61] C. B. Hall, C. E. Long, K. C. Schnabel, Respiratory syncytial virus infections in previously healthy working adults, Clin Infect Dis 33 (6) (2001) 792-6. doi:10.1086/322657.

[62] A. Weber, M. Weber, P. Milligan, Modeling epidemics caused by respiratory syncytial virus (RSV), Math Biosci 172 (2) (2001) 95-113. doi:10.1016/s0025-5564(01)00066-9.

[ [63] CDC, Rsv transmission, https://www.cdc.gov/rsv/about/ transmission.html.

[64] K. G. Nicholson, J. Kent, V. Hammersley, E. Cancio, Risk factors for lower respiratory complications of rhinovirus infections in elderly people 
1119-23. doi:10.1136/bmj.313.7065.1119.

[65] E. Arruda, A. Pitkäranta, T. J. Witek, Jr, C. A. Doyle, F. G. Hayden, Frequency and natural history of rhinovirus infections in adults during autumn, J Clin Microbiol 35 (11) (1997) 2864-8.

[66] R. G. Douglas, Jr, T. R. Cate, P. J. Gerone, R. B. Couch, Quantitative rhinovirus shedding patterns in volunteers, Am Rev Respir Dis 94 (2) (1966) 159-67. doi:10.1164/arrd.1966.94.2.159.

[67] M. L. Landry, Rhinoviruses, in: P. Murray, E. Baron, J. Jorgensen, M. Landry, M. Pfaller (Eds.), Manual of clinical microbiology, 9th Edition, Washington, DC, 2007, p. 1405.

[68] L. Kaiser, N. Regamey, H. Roiha, C. Deffernez, U. Frey, Human coronavirus NL63 associated with lower respiratory tract symptoms in early life, Pediatr Infect Dis J 24 (11) (2005) 1015-7. doi:10.1097/01.inf. 0000183773.80217 .12

[69] S. S. Chiu, K. H. Chan, K. W. Chu, S. W. Kwan, Y. Guan, L. L. M. Poon, J. S. M. Peiris, Human coronavirus NL63 infection and other coronavirus infections in children hospitalized with acute respiratory disease in Hong Kong, China, Clin Infect Dis 40 (12) (2005) 1721-9. doi:10.1086/430301

[70] J. Y. Hong, H. J. Lee, P. A. Piedra, E. H. Choi, K. H. Park, Y. Y. Koh, W. S. Kim, Lower respiratory tract infections due to adenovirus in hospitalized Korean children: epidemiology, clinical features, and prognosis, Clin Infect Dis 32 (10) (2001) 1423-9. doi:10.1086/320146

[71] H. W. Kim, C. D. Brandt, J. O. Arrobio, B. Murphy, R. M. Chanock, R. H. Parrott, Influenza A and B virus infection in infants and young children during the years 1957-1976, Am J Epidemiol 109 (4) (1979) 46479. doi:10.1093/oxfordjournals.aje.a112704. 
[72] A. Drăgănescu, O. Săndulescu, D. Florea, O. Vlaicu, A. Streinu-Cercel, D. Oţelea, V. Aramă, M. L. Luminos, A. Streinu-Cercel, M. Niţescu, A. Ivanciuc, R. Bacruban, D. Piţigoi, The influenza season 2016/17 in Bucharest, Romania - surveillance data and clinical characteristics of patients with influenza-like illness admitted to a tertiary infectious diseases hospital, Braz J Infect Dis 22 (5) (2018) 377-386. doi:10.1016/j.bjid. 2018.10 .275

[73] S. Broor, F. S. Dawood, B. G. Pandey, S. Saha, V. Gupta, A. Krishnan, S. Rai, P. Singh, D. Erdman, R. B. Lal, Rates of respiratory virusassociated hospitalization in children aged $<5$ years in rural northern India, J Infect 68 (3) (2014) 281-9. doi:10.1016/j.jinf.2013.11.005.

[74] T. S. Howard, L. H. Hoffman, P. E. Stang, E. A. Simoes, Respiratory syncytial virus pneumonia in the hospital setting: length of stay, charges, and mortality, J Pediatr 137 (2) (2000) 227-32. doi:10.1067/mpd.2000. 107525 .

[75] B. M. Morrow, M. Hatherill, H. E. M. Smuts, J. Yeats, R. Pitcher, A. C. Argent, Clinical course of hospitalised children infected with human metapneumovirus and respiratory syncytial virus, J Paediatr Child Health 42 (4) (2006) 174-8. doi:10.1111/j.1440-1754.2006.00825.x.

[76] D. K. Shay, R. C. Holman, R. D. Newman, L. L. Liu, J. W. Stout, L. J. Anderson, Bronchiolitis-associated hospitalizations among US children, 】 1980-1996, JAMA 282 (15) (1999) 1440-6. doi:10.1001/jama.282.15. 1440 .

[77] S. S. Chiu, K.-H. Chan, H. Chen, B. W. Young, W. Lim, W. H.-S. Wong, J. S. M. Peiris, Virologically confirmed population-based burden of hospitalization caused by respiratory syncytial virus, adenovirus, and parainfluenza viruses in children in Hong Kong, Pediatr Infect Dis J 29 (12) (2010) 1088-92. doi:10.1097/INF.0b013e3181e9de24. 

of human rhinovirus positivity in hospitalized children, Ann Thorac Med 13 (4) (2018) 230-236. doi:10.4103/atm.ATM_291_17.

[79] M. K. Iwane, M. M. Prill, X. Lu, E. K. Miller, K. M. Edwards, C. B. Hall, M. R. Griffin, M. A. Staat, L. J. Anderson, J. V. Williams, G. A. Weinberg, A. Ali, P. G. Szilagyi, Y. Zhu, D. D. Erdman, Human rhinovirus species associated with hospitalizations for acute respiratory illness in young US children, J Infect Dis 204 (11) (2011) 1702-10. doi:10.1093/infdis/ jir634.

[80] G. Boivin, M. Baz, S. Côté, R. Gilca, C. Deffrasnes, E. Leblanc, M. G. Bergeron, P. Déry, G. De Serres, Infections by human coronavirus-NL in hospitalized children, Pediatr Infect Dis J 24 (12) (2005) 1045-8. doi: 10.1097/01.inf.0000183743.68569.c7.

[81] V. M. Corman, A. M. Albarrak, A. S. Omrani, M. M. Albarrak, M. E. Farah, M. Almasri, D. Muth, A. Sieberg, B. Meyer, A. M. Assiri, T. Binger, K. Steinhagen, E. Lattwein, J. Al-Tawfiq, M. A. Müller, C. Drosten, Z. A. Memish, Viral shedding and antibody response in 37 patients with Middle East Respiratory Syndrome Coronavirus infection, Clin Infect Dis 62 (4) (2016) 477-483. doi:10.1093/cid/civ951.

[82] N. Peled, C. Nakar, H. Huberman, E. Scherf, Z. Samra, Y. Finkelstein, V. Hoffer, B.-Z. Garty, Adenovirus infection in hospitalized immunocompetent children, Clin Pediatr (Phila) 43 (3) (2004) 223-9. doi: $10.1177 / 000992280404300303$.

[83] M. K. Iwane, K. M. Edwards, P. G. Szilagyi, F. J. Walker, M. R. Griffin, G. A. Weinberg, C. Coulen, K. A. Poehling, L. P. Shone, S. Balter, C. B. Hall, D. D. Erdman, K. Wooten, B. Schwartz, New Vaccine Surveillance Network, Population-based surveillance for hospitalizations associated with respiratory syncytial virus, influenza virus, and parain- 
fluenza viruses among young children, Pediatrics 113 (6) (2004) 1758-64. doi:10.1542/peds.113.6.1758.

[84] A. J. Millman, C. Reed, P. D. Kirley, D. Aragon, J. Meek, M. M. Farley, P. Ryan, J. Collins, R. Lynfield, J. Baumbach, S. Zansky, N. M. Bennett, B. Fowler, A. Thomas, M. L. Lindegren, A. Atkinson, L. Finelli, S. S. Chaves, Improving accuracy of influenza-associated hospitalization rate estimates, Emerg Infect Dis 21 (9) (2015) 1595-601. doi: 10.3201/eid2109.141665

[85] L. W. Ang, C. Lim, V. J. M. Lee, S. Ma, W. W. Tiong, P. L. Ooi, R. T. P. Lin, L. James, J. Cutter, Influenza-associated hospitalizations, Singapore, 2004-2008 and 2010-2012, Emerg Infect Dis 20 (10) (2014) 1652-60. doi: 10.3201/eid2010.131768

[86] A. R. Falsey, E. E. Walsh, M. T. Esser, K. Shoemaker, L. Yu, M. P. Griffin, Respiratory syncytial virus-associated illness in adults with advanced chronic obstructive pulmonary disease and/or congestive heart failure, J Med Virol 91 (1) (2019) 65-71. doi:10.1002/jmv.25285.

[87] J. P. Mullooly, C. B. Bridges, W. W. Thompson, J. Chen, E. Weintraub, L. A. Jackson, S. Black, D. K. Shay, Vaccine Safety Datalink Adult Working Group, Influenza- and RSV-associated hospitalizations among adults, Vaccine 25 (5) (2007) 846-55. doi:10.1016/j.vaccine.2006.09.041.

[88] L. F. Avendaño, M. A. Palomino, C. Larrañaga, Surveillance for respiratory syncytial virus in infants hospitalized for acute lower respiratory infection in Chile (1989 to 2000), J Clin Microbiol 41 (10) (2003) 4879-82. doi:10.1128/jcm.41.10.4879-4882.2003

[89] E. K. Miller, J. Linder, D. Kraft, M. Johnson, P. Lu, B. R. Saville, J. V. Williams, M. R. Griffin, H. K. Talbot, Hospitalizations and outpatient visits for rhinovirus-associated acute respiratory illness in adults, J Allergy Clin Immunol 137 (3) (2016) 734-43.e1. doi:10.1016/j.jaci.2015.06. 017. 
[90] W.-M. Lee, R. F. Lemanske, Jr, M. D. Evans, F. Vang, T. Pappas, R. Gangnon, D. J. Jackson, J. E. Gern, Human rhinovirus species and season of infection determine illness severity, Am J Respir Crit Care Med 186 (9) (2012) 886-91. doi:10.1164/rccm.201202-03300C.

[91] N. Bastien, K. Anderson, L. Hart, P. Van Caeseele, K. Brandt, D. Milley, T. Hatchette, E. C. Weiss, Y. Li, Human coronavirus nl63 infection in Canada, J Infect Dis 191 (4) (2005) 503-6. doi:10.1086/426869.

[92] J. Reina, C. López-Causapé, E. Rojo-Molinero, R. Rubio, Clinicoepidemiological characteristics of acute respiratory infections caused by coronavirus OC43, NL63 and 229E, Rev Clin Esp 214 (9) (2014) 499-504. doi:10.1016/j.rce.2014.05.020

[93] M. R. Hilleman, R. L. Gauld, R. L. Butler, R. A. Stallones, C. L. Hedberg, M. S. Warfield, S. A. Anderson, Appraisal of occurrence of adenoviruscaused respiratory illness in military populations, Am J Hyg 66 (1) (1957) 29-41. doi:10.1093/oxfordjournals.aje.a119882.

[94] W. P. Glezen, A. A. Payne, D. N. Snyder, T. D. Downs, Mortality and influenza, Journal of Infectious Diseases 146 (3) (1982) 313-321.

[95] C. Cohen, S. Walaza, F. K. Treurnicht, M. McMorrow, S. A. Madhi, J. M. McAnerney, S. Tempia, In- and out-of-hospital mortality associated with seasonal and pandemic influenza and respiratory syncytial virus in South Africa, 2009-2013, Clin Infect Dis 66 (1) (2018) 95-103. doi:10.1093/ cid/cix740.

[96] W. J. Alonso, C. Viboud, L. Simonsen, E. W. Hirano, L. Z. Daufenbach, M. A. Miller, Seasonality of influenza in Brazil: a traveling wave from the Amazon to the subtropics, Am J Epidemiol 165 (12) (2007) 1434-42. doi:10.1093/aje/kwm012

[97] T. M. Quandelacy, C. Viboud, V. Charu, M. Lipsitch, E. Goldstein, Ageand sex-related risk factors for influenza-associated mortality in the United 
[98] N. I. Mendez-Dominguez, L. O. Bobadilla-Rosado, L. S. Fajardo-Ruiz, A. Camara-Salazar, S. Gomez-Carro, Influenza in Yucatan in 2018: Chronology, characteristics and outcomes of ambulatory and hospitalized patients, Braz J Infect Dis 23 (5) (2019) 358-362. doi:10.1016/j.bjid. 2019.08 .009

[99] R. C. Welliver, Sr, P. A. Checchia, J. H. Bauman, A. W. Fernandes, P. J. Mahadevia, C. B. Hall, Fatality rates in published reports of RSV hospitalizations among high-risk and otherwise healthy children, Curr Med Res Opin 26 (9) (2010) 2175-81. doi:10.1185/03007995.2010.505126.

[100] M. N. Tsolia, D. Kafetzis, K. Danelatou, H. Astral, K. Kallergi, P. Spyridis, T. E. Karpathios, Epidemiology of respiratory syncytial virus bronchiolitis in hospitalized infants in Greece, Eur J Epidemiol 18 (1) (2003) 55-61. doi:10.1023/a:1022556215190.

[101] N. Lee, S. T. Qureshi, Other viral pneumonias: coronavirus, respiratory syncytial virus, adenovirus, hantavirus, Crit Care Clin 29 (4) (2013) 104568. doi:10.1016/j.ccc.2013.07.003.

[102] A. Fica, J. Dabanch, W. Andrade, P. Bustos, I. Carvajal, C. Ceroni, V. Triantafilo, M. Castro, R. Fasce, Clinical relevance of rhinovirus infections among adult hospitalized patients, Braz J Infect Dis 19 (2) (2015) 118-24. doi:10.1016/j.bjid.2014.10.003

[103] A. R. Falsey, E. E. Walsh, F. G. Hayden, Rhinovirus and coronavirus infection-associated hospitalizations among older adults, J Infect Dis 185 (9) (2002) 1338-41. doi:10.1086/339881.

[104] N. Ramadan, H. Shaib, Middle East respiratory syndrome coronavirus 口 (MERS-CoV): A review, Germs 9 (1) (2019) 35-42. doi:10.18683/ germs.2019.1155, 
[105] H.-J. Chang, Estimation of basic reproduction number of the Middle East respiratory syndrome coronavirus (MERS-CoV) during the outbreak in South Korea, 2015, Biomed Eng Online 16 (1) (2017) 79. doi:10.1186/ s12938-017-0370-7.

[106] A. G. Wesley, M. Pather, D. Tait, Nosocomial adenovirus infection in a (1) paediatric respiratory unit, J Hosp Infect 25 (3) (1993) 183-90. doi: 10.1016/0195-6701(93)90036-y.

[107] S. I. Gerber, D. D. Erdman, S. L. Pur, P. S. Diaz, J. Segreti, A. E. Kajon, R. P. Belkengren, R. C. Jones, Outbreak of adenovirus genome type $7 \mathrm{~d} 2$ infection in a pediatric chronic-care facility and tertiary-care hospital, Clin Infect Dis 32 (5) (2001) 694-700. doi:10.1086/319210.

[108] C. Larrañaga, J. Martínez H, A. Palomino M, M. Peña C, F. Carrión A, L. F. Avendaño C, Molecular characterization of hospital-acquired adenovirus infantile respiratory infection in Chile using species-specific PCR assays, J Clin Virol 39 (3) (2007) 175-81. doi:10.1016/j.jcv.2007.04. 016 .

[109] J.-H. Ko, H.-T. Woo, H. S. Oh, S. M. Moon, J. Y. Choi, J. U. Lim, D. Kim, J. Byun, S.-H. Kwon, D. Kang, J. Y. Heo, K. R. Peck, Ongoing outbreak of human adenovirus-associated acute respiratory illness in the Republic of Korea military, 2013 to 2018, Korean J Intern Meddoi:10. 3904/kjim.2019.092.

[110] J. Wallinga, M. Lipsitch, How generation intervals shape the relationship between growth rates and reproductive numbers, Proc Biol Sci 274 (1609) (2007) 599-604. doi:10.1098/rspb.2006.3754.

[111] B. F. d. Blasio, B. G. Iversen, G. S. Tomba, Effect of vaccines and antivirals during the major 2009 A(H1N1) pandemic wave in Norwayand the influence of vaccination timing, PLoS One 7 (1) (2012) e30018. 
[112] C. Sonthichai, S. Iamsirithaworn, D. Cummings, P. Shokekird, A. Niramitsantipong, S. Khumket, M. Chittaganpitch, J. Lessler, Effectiveness of non-pharmaceutical interventions in controlling an influenza A outbreak in a school, Thailand, November 2007, Outbreak Surveill Investig Rep 4 (2) (2011) 611.

[113] G. Chowell, M. A. Miller, C. Viboud, Seasonal influenza in the United States, France, and Australia: transmission and prospects for control, Epidemiol Infect 136 (6) (2008) 852-64. doi:10.1017/S0950268807009144.

[114] G. Chowell, C. Viboud, L. Simonsen, M. Miller, W. J. Alonso, The reproduction number of seasonal influenza epidemics in Brazil, 1996-2006, Proc Biol Sci 277 (1689) (2010) 1857-66. doi:10.1098/rspb.2009.1897.

[115] M. Biggerstaff, S. Cauchemez, C. Reed, M. Gambhir, L. Finelli, Estimates of the reproduction number for seasonal, pandemic, and zoonotic influenza: a systematic review of the literature, BMC Infect Dis 14 (2014) 480. doi : 10.1186/1471-2334-14-480.

[116] J. Reis, J. Shaman, Retrospective parameter estimation and forecast of respiratory syncytial virus in the United States, PLoS Comput Biol 12 (10) (2016) e1005133. doi:10.1371/journal.pcbi.1005133.

[117] J. X. Velasco-Hernández, M. Núñez-López, A. Comas-García, D. E. N. Cherpitel, M. C. Ocampo, Superinfection between influenza and RSV alternating patterns in San Luis Potosí State, México, PLoS One 10 (3) (2015) e0115674. doi:10.1371/journal.pone.0115674.

[118] V. R. Duvvuri, A. Granados, P. Rosenfeld, J. Bahl, A. Eshaghi, J. B. Gubbay, Genetic diversity and evolutionary insights of respiratory syncytial virus a ON1 genotype: global and local transmission dynamics, Sci Rep 5 (2015) 14268. doi:10.1038/srep14268

[119] V. E. Pitzer, C. Viboud, W. J. Alonso, T. Wilcox, C. J. Metcalf, C. A. Steiner, A. K. Haynes, B. T. Grenfell, Environmental drivers of the spa- 
tiotemporal dynamics of respiratory syncytial virus in the United States,

[120] J. Reis, J. Shaman, Simulation of four respiratory viruses and inference of epidemiological parameters, Infect Dis Model 3 (2018) 23-34. doi: $10.1016 /$ j.idm.2018.03.006.

[121] N. Levy, M. Iv, E. Yom-Tov, Modeling influenza-like illnesses through composite compartmental models, Physica A: Statistical Mechanics and its Applications 494 (2018) 288-293.

[122] E. J. Scully, S. Basnet, R. W. Wrangham, M. N. Muller, E. Otali, D. Hyeroba, K. A. Grindle, T. E. Pappas, M. E. Thompson, Z. Machanda, K. E. Watters, A. C. Palmenberg, J. E. Gern, T. L. Goldberg, Lethal respiratory disease associated with human rhinovirus $\mathrm{C}$ in wild chimpanzees, Uganda, 2013, Emerg Infect Dis 24 (2) (2018) 267-274. doi: 10.3201/eid2402.170778

[123] M. S. Majumder, C. Rivers, E. Lofgren, D. Fisman, Estimation of MERS-Coronavirus reproductive number and case fatality rate for the spring 2014 Saudi Arabia outbreak: Insights from publicly available data, PLoS Curr 6. doi:10.1371/currents.outbreaks. 98d2f8f3382d84f390736cd5f5fe133c.

[124] G. M. Leung, P.-H. Chung, T. Tsang, W. Lim, S. K. K. Chan, P. Chau, C. A. Donnelly, A. C. Ghani, C. Fraser, S. Riley, N. M. Ferguson, R. M. Anderson, Y.-l. Law, T. Mok, T. Ng, A. Fu, P.-Y. Leung, J. S. M. Peiris, T.-H. Lam, A. J. Hedley, SARS-CoV antibody prevalence in all Hong

(1) Kong patient contacts, Emerg Infect Dis 10 (9) (2004) 1653-6. doi: 10.3201/eid1009.040155

[125] Y. Kim, S. Lee, C. Chu, S. Choe, S. Hong, Y. Shin, The characteristics of Middle Eastern Respiratory Syndrome Coronavirus transmission dynam- 
ics in South Korea, Osong Public Health Res Perspect 7 (1) (2016) 49-55. doi:10.1016/j.phrp.2016.01.001.

[126] M. Lipsitch, T. Cohen, B. Cooper, J. M. Robins, S. Ma, L. James,

[127] C. T. Bauch, J. O. Lloyd-Smith, M. P. Coffee, A. P. Galvani, Dynam-

[131] F. M. Hamelin, L. J. Allen, V. A. Bokil, L. J. Gross, F. M. Hilker, M. J. Jeger, C. A. Manore, A. G. Power, M. A. Rúa, N. J. Cunniffe, Coinfections by noninteracting pathogens are not independent and require new tests of interaction, PLoS biology 17 (12) (2019) e3000551. 
[132] A. Wu, V. T. Mihaylova, M. L. Landry, E. F. Foxman, Interference between rhinovirus and influenza a virus: a clinical data analysis and experimental infection study, The Lancet Microbe 1 (6) (2020) e254-e262.

[133] P. Van den Driessche, J. Watmough, Reproduction numbers and subthreshold endemic equilibria for compartmental models of disease trans- 
medRxiv preprint doi: https://doi.org/10.1101/2020.02.04.20020404; this version posted April 23, 2021. The copyright holder for this preprint (which was not certified by peer review) is the author/funder, who has granted medRxiv a license to display the preprint in perpetuity.

It is made available under a CC-BY-NC 4.0 International license .

Spencer et al. ILI Review page 20

\begin{tabular}{|c|c|c|c|c|c|c|c|c|c|c|c|c|}
\hline $\begin{array}{l}\text { parameter } \\
\text { (Influenza A \& B) }\end{array}$ & type of study & study time & population & sample size & strain & definition of & method & notes & patient age & range & mean & citation \\
\hline ation period & experimental & 30 days & healthy adults & 17 & seasonal & $\begin{array}{l}\text { inoculation to peak } \\
\text { symptoms }\end{array}$ & & & adult & $\begin{array}{l}2.4 \text { days } \\
\text { median } 3.3\end{array}$ & 3 days & 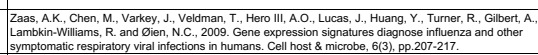 \\
\hline & experimental & 8 days & healthy males & 16 & FIUA (H1N1) & $\begin{array}{l}\text { inoculation to } \\
\text { occurrence of } \\
\text { symptoms }\end{array}$ & & & $19-35$ & $1-3$ days & 2 days & 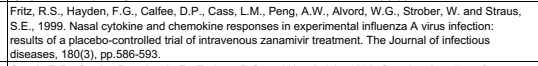 \\
\hline & experimental & 49 days & male inmates & 43 & $\begin{array}{l}\begin{array}{l}\text { FluA (Hong } \\
\text { Kong) }\end{array} \\
\end{array}$ & inoculation to onset & & & $21-40$ & $2-3$ days & 2.5 days & 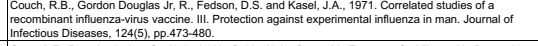 \\
\hline & observational & & $\begin{array}{l}\text { admitted to } \\
\text { hospital }\end{array}$ & 8 & seasonal & exposure to onset & & $\begin{array}{l}\text { exposed to } \\
\text { dissaasedddead } \\
\text { chickens }\end{array}$ & $5-15$ & 3.7-6. 3 days & 5 days & 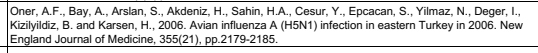 \\
\hline & observational & & airline passengers & 54 & FluA(H5N1) & airline delay to onset & & & & $1-3$ days & 1.5 days & 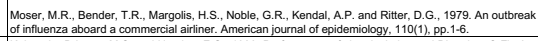 \\
\hline & experimental & 8 days & healthy adults & 14 & FIUA(H1N1) & inoculation to onset & & & $19-40$ & $2-3$ days & 2.5 days & 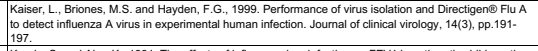 \\
\hline & observational & & asthmatic children & 20 & NA & & & & 43689 & $2-3$ days & 2.5 days & $\begin{array}{l}\text { Kondo, S. and Abe, K, 1991. The effects of finfluenzza virus infection on FEV1 in asthmatic children: the } \\
\text { time-course study. Chest, 100(5), p. } 1235 \text {-1238. }\end{array}$ \\
\hline & $\begin{array}{l}\text { Systematic } \\
\text { review }\end{array}$ & & & & & $\begin{array}{l}\text { inoculation to onset of } \\
\text { symptoms }\end{array}$ & & $\begin{array}{l}\begin{array}{l}\text { range and } \\
\text { central tendency }\end{array} \\
\text { con }\end{array}$ & all & $1-4$ days & 2 days & 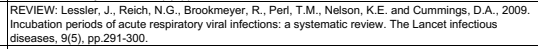 \\
\hline & review & before 2004 & literature & & & & & & & $1-4$ days & 2.5 & $\begin{array}{l}\text { REVIEW: Wat, D., 2004. The common cold: a review of the literature. European Journal of Intermal } \\
\text { Medicine, 15(2). pp.79-88. }\end{array}$ \\
\hline \multirow{8}{*}{ infectious period } & & & & & & & & & & & & \\
\hline & experimental & 8 days & healthy males & & FluA(H1N1) & & virus titer & $\begin{array}{l}\text { mean viral } \\
\text { shedding period } \\
4.6 \text { days }\end{array}$ & $19-35$ & $3.1-5.7$ days & 4.6 days & 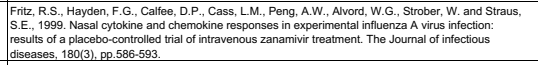 \\
\hline & experimental & 49 days & male inmates & & $\begin{array}{l}\begin{array}{l}\text { FluA (Hong } \\
\text { Kong) }\end{array} \\
\end{array}$ & & & & $21-40$ & $2-9$ days & 5.5 days & 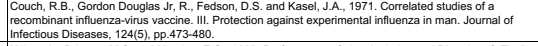 \\
\hline & experimental & & & & & & & & $19-40$ & 1-8 days & 4.5 days & 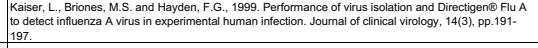 \\
\hline & & 14 days & ferrets & 8 & FILAA(H1N1) & & $\begin{array}{l}\text { culture + RT- } \\
P C R \text {, titer }\end{array}$ & & & 2 days & 2 days & \\
\hline & observational & & index contacts & 350 & seasonal & & culture + RT-PCR & & all & & 2 days & 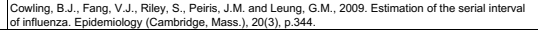 \\
\hline & experimental & 1 year & $\begin{array}{l}\text { otherwise healthy } \\
\text { LLI children }\end{array}$ & & seasonal & & & & $\begin{array}{l}6 \text { months-10 } \\
\text { yrs }\end{array}$ & & 8.9 days & 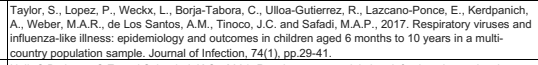 \\
\hline & observational & $1975-1995$ & healthy adults & 59 & seasonal & $\begin{array}{l}\text { mean duration of } \\
\text { illness }\end{array}$ & & & adult & & 6.8 days & 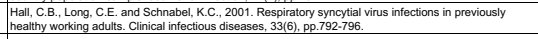 \\
\hline \multicolumn{13}{|l|}{$\begin{array}{l}\text { hospitalization } \\
\text { period }\end{array}$} \\
\hline & observational & $\begin{array}{l}31 \text { days } \\
(2016)\end{array}$ & $\begin{array}{l}\text { confimed FluB } \\
\text { outrereak in } \\
\text { hospital }\end{array}$ & & & $\begin{array}{l}\text { mean length of hosp. } \\
\text { stay }\end{array}$ & & & & & 11.3 days & 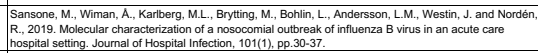 \\
\hline & retrospective & 19 years & $\begin{array}{l}\text { respiratory disease } \\
\text { patients }\end{array}$ & & & & & & 0.72 months & & 8 days & 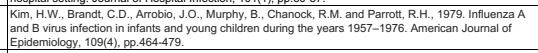 \\
\hline & observational & 2016-2017 & |LL patients & & & & & & all & $4-6$ days & 5 days & 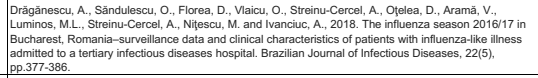 \\
\hline & experimental & 1 year & $\begin{array}{l}\text { lotherwise enealthy } \\
\text { ILI children }\end{array}$ & & seasonal & & & & $\begin{array}{l}6 \text { month } \\
\text { yrs }\end{array}$ & & 4 days & 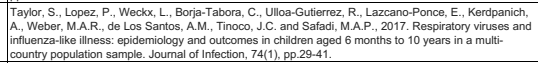 \\
\hline
\end{tabular}


medRxiv preprint doi: https://doi.org/10.1101/2020.02.04.20020404; this version posted April 23, 2021. The copyright holder for this preprint (which was not certified by peer review) is the author/funder, who has granted medRxiv a license to display the preprint in perpetuity.

It is made available under a CC-BY-NC 4.0 International license .

Spencer et al. ILI Review page 21

\begin{tabular}{|c|c|c|c|c|c|c|c|c|c|c|c|}
\hline & observational & 2009-2011 & children $<5$ & 17 & & $\begin{array}{l}\text { median length of } \\
\text { hospital stay }\end{array}$ & & $<5$ & 3.4 days & 3.5 days & 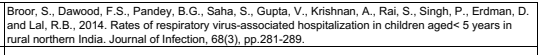 \\
\hline \multicolumn{12}{|l|}{$\begin{array}{l}\text { hospitalization } \\
\text { proportion }\end{array}$} \\
\hline & observational & 1 season & children & & & $\begin{array}{l}\text { number hospitalized } \\
\text { out of } 1,000\end{array}$ & & $<5$ & & 0.0006 & 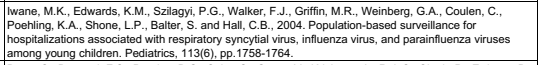 \\
\hline & observational & 2009-2011 & children $<5$ in India & 245 & & $\begin{array}{l}\text { numer hospitalized out } \\
\text { of } 10,000\end{array}$ & & $<5$ & & 0.0012 & 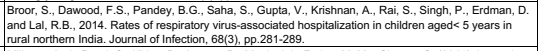 \\
\hline & \begin{tabular}{|l} 
retrospoective, \\
adjusted
\end{tabular} & 2003-2013 & all population & & & $\begin{array}{l}\text { number hospitilized } \\
\text { out of } 100,000\end{array}$ & $\begin{array}{l}\text { PCR, culture, } \\
\text { DFA, RIDT }\end{array}$ & all & $\begin{array}{l}0.00003- \\
0.0018\end{array}$ & 0.00092 & 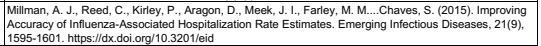 \\
\hline & observational & 2004-2008 & all population & & & $\begin{array}{l}\text { number hospitalized } \\
\text { out of } 100,000\end{array}$ & & $\begin{array}{l}<6 \text { months- } \\
275 \text { yrs }\end{array}$ & & 0.00028 & 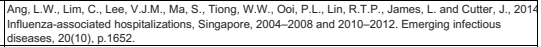 \\
\hline & observational & 2010-2012 & all population & & & $\begin{array}{l}\text { number hospitalized } \\
\text { out of } 100,000\end{array}$ & & $\begin{array}{l}<6 \text { months- } \\
275 \text { yrs }\end{array}$ & & 0.0003 & 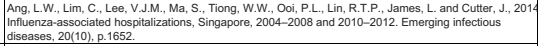 \\
\hline & observational & 1 year & $\begin{array}{l}\text { otherwise healthy } \\
\text { lli children }\end{array}$ & 476 & seasonal & $\begin{array}{l}\text { number hospitalized } \\
\text { out of } 476\end{array}$ & & \begin{tabular}{|c|c|c|c|c|}
6 months-10 \\
yrs
\end{tabular} \mid & & 0.019 & 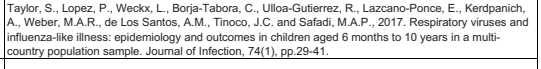 \\
\hline \multicolumn{12}{|l|}{ case fatality rate } \\
\hline & observational & 2009-2013 & $\begin{array}{l}\text { out of all } \\
\text { respiratory }\end{array}$ & $\begin{array}{l}4378 \\
\text { annually }\end{array}$ & & per person-year & & & & 0.00023 & 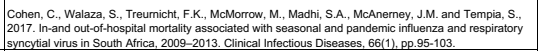 \\
\hline & retrospective & 1979-2001 & $\begin{array}{l}\text { all registered } \\
\text { deaths in Brazil }\end{array}$ & 19 million & $\begin{array}{l}\text { seasonal } \\
\text { influenza }\end{array}$ & Brazil govt. data & & all & & 0.003 & 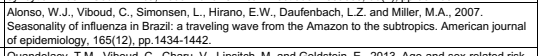 \\
\hline & retrospective & 1997-2007 & all U.S. & & $\begin{array}{l}\text { Seasonal } \\
\text { influenza }\end{array}$ & & & all & & 0.07 & 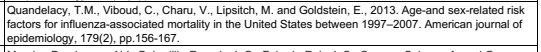 \\
\hline & observational & 2018 & $\begin{array}{l}\text { hospitalized ILI } \\
\text { patients }\end{array}$ & & $\begin{array}{l}\begin{array}{l}\text { Sesasonal } \\
\text { influenza }\end{array} \\
\text { nat }\end{array}$ & & & all & & 0.0827 & 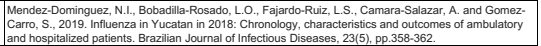 \\
\hline & retrospective & 1990-2008 & New Zealand & & $\begin{array}{l}\text { seasonal } \\
\text { influenza }\end{array}$ & $\begin{array}{l}\text { deaths per } 100,000 \\
\text { persons pery year }\end{array}$ & & all & & 0.000106 & 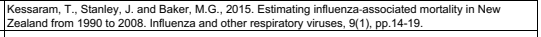 \\
\hline & from clinical & & & & Flu & & & & & 1.73 & $\begin{array}{l}\text { Wallinga, J. and Lipsitch, M., 2006. How generation intervals shape the relationship between growth } \\
\text { rates and reproductive numbers. Procoedings of the Royal Society B: Bilogogical sciences, 274(1609), } \\
\text { pp.599-604. }\end{array}$ \\
\hline & estimated & & & & FIUA(H1N1) & & & & 1.06-1.69 & 1.35 & 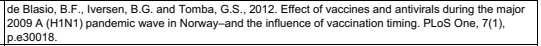 \\
\hline & estimated & & & & FluA(H1N1) & & & & & 3.4 & 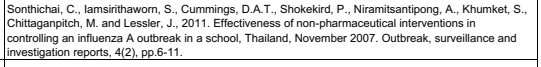 \\
\hline & estimated & 1972-1997 & $\begin{array}{l}\text { USA, France, } \\
\text { Australia }\end{array}$ & & seasonal & 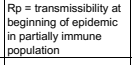 & & & & 1.3 & 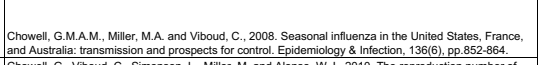 \\
\hline & estimated & 1996-2006 & Brazil & & seasonal & & & & & 1.03 & 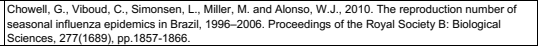 \\
\hline & \begin{tabular}{|l}
$\begin{array}{l}\text { estimated } \\
\text { (review) }\end{array}$ \\
(n)
\end{tabular} & & & 24 studies & seasonal & & & & & 1.28 & 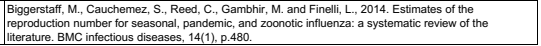 \\
\hline
\end{tabular}


medRxiv preprint doi: https://doi.org/10.1101/2020.02.04.20020404; this version posted April 23, 2021. The copyright holder for this preprint (which was not certified by peer review) is the author/funder, who has granted medRxiv a license to display the preprint in perpetuity. It is made available under a CC-BY-NC 4.0 International license .

\begin{tabular}{|c|c|c|c|c|c|c|c|c|c|c|c|}
\hline 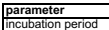 & type of study & study time & population & sample size & strain & definition of parameter & notes & patient age 1 & Trange & mean & Spencer et al. ILIReview page 22 \\
\hline & systematic review & & & review article & & & \begin{tabular}{|l|l}
$\begin{array}{l}\text { range and } \\
\text { central tendency }\end{array}$ \\
(a)
\end{tabular} & & 3.7 days & 5 days & $\begin{array}{l}\text { REVIEW: Lessler, J., Reich, N.G., Brookmeyer, R., Perl, T.M., Nelson, K.E. and Cummings, D.A., 2009. } \\
\text { Incubation periods of acute respiratory viral infections: a systematic review. The Lancet infectious diseases, } \\
\text { 9(5), pp.291-300. }\end{array}$ \\
\hline & experimental & 30 days & healthy adults & 20 & RSV & $\begin{array}{l}\text { inoculation to peak } \\
\text { symptoms }\end{array}$ & & adult & $\begin{array}{l}4.7 \text { days, median } \\
5.9\end{array}$ & 5.5 days & 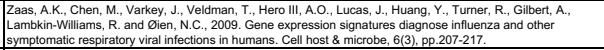 \\
\hline & experimental & 10 days & adult males & 41 & RSV & & & adult & $3-7$ days & 4 days & $\begin{array}{l}\text { Johnson KM, Chanock RM, Rikkind D, Dravetz HM, Knight V. 1961. Respiratory syncytial virus infection in } \\
\text { adult volunteers. J.A.M.A. 176:663-677, } 1961 \text {. }\end{array}$ \\
\hline & experimental & 10 days & healthy adults & 22 & RSV & \begin{tabular}{l|} 
inoculation to presence of \\
virus
\end{tabular} & 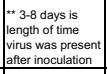 & $21-50 \mathrm{yrs}$ & 3-8 days & 3 days & 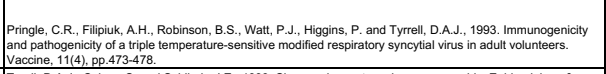 \\
\hline & experimental & 5 days & adults & 36 & RSV & $\begin{array}{l}\text { linoculation to peak } \\
\text { symptoms }\end{array}$ & & adult & $4-5$ days & 5 days & $\begin{array}{l}\text { Tyrell, D.A.J., Cohen, S. and Schilarb, J.E., 1993. Signs and symptoms in common colds. Epidemiology \& } \\
\text { Infection, 111(1), pp.143-156. }\end{array}$ \\
\hline & review & before 2004 & literature & NA & & & & & $4-5$ days & 4.5 days & $\begin{array}{l}\text { REVIEW: Wat, } D \text {., 2004. The common cold: a review of the literature. European Journal of Internal Medicine, } \\
\text { 15(2), pp.79-88. }\end{array}$ \\
\hline infectious period & & & & & & & & & & & \\
\hline & observational & 1975-1995 & healthy adults & 211 & NA & mean duration of illness & & adult & & 9.5 days & $\begin{array}{l}\text { Hall, C.B., Long, C.E. and Schnabel, K.C., 2001. Respiratory syncytial virus infections in previously healthy } \\
\text { working adults. Clinical infectious diseases, 33(6), pp.792-796. }\end{array}$ \\
\hline & observational & $<=1976$ & $\begin{array}{ll}\text { hospitalized } \\
\text { infants RSV }\end{array}$ & 23 & & $\begin{array}{l}\text { duration of RSV viral } \\
\text { shedding }\end{array}$ & & infants & $1-21$ days & 6.7 days & $\begin{array}{l}\text { Weber, A. Weber, M. and Miligan, } \mathrm{P}, 2001.1 \text {. Modeling epidemics caused by respiratory syncytial virus (RSV). } \\
\text { Mathematical biosciences, } 172(2) \text {, pp.95-113. }\end{array}$ \\
\hline & {$[\mathrm{NA}$ (source: $\mathrm{CDC}$ ) } & $\mathrm{NA}$ & NA & & & $\begin{array}{l}\text { mean duration of } \\
\text { contagious period }\end{array}$ & & all & $3-8$ days & 5.5 days & CDC, "RSV Transmission," https://www..cdc.gov/rsvlabouttransmission.htm| \\
\hline & experimental & 1 year & $\begin{array}{l}\begin{array}{l}\text { otherwise } \\
\text { healthy III } \\
\text { children }\end{array} \\
\end{array}$ & 235 & & $\begin{array}{l}\text { mean duration of ILI } \\
\text { episode }\end{array}$ & & \begin{tabular}{|l|l|l}
6 months-10 \\
$y$ ys
\end{tabular} & & 9.2 days & 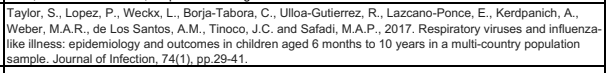 \\
\hline hospitalization & & & & & & & & & & & \\
\hline & observational & 1993-1995 & children $<=4$ & 10767 & NA & $\begin{array}{l}\text { number of days from } \\
\text { admittance to discharge }\end{array}$ & & $<=4 \mathrm{yrs}$ & & 4.9 days & $\begin{array}{l}\text { Howard, T.S., Hoffman, L..., Stang, P.E. and Simoes, E.A., 2000. Respiratory syncytial virus pneumonia in } \\
\text { the hospital setting: length of stay, charges, and mortality. The Journal of pediatrics, } 137(2) \text {, pp.227-232. }\end{array}$ \\
\hline & observational & 2001-2003 & hosp. respiratory & 413 & & $\begin{array}{l}\text { median duration of } \\
\text { hospital stay in days }\end{array}$ & & all & 6-17.5 days & 9.5 days & 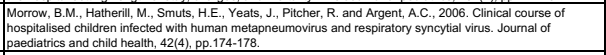 \\
\hline & observational & 1980-1996 & \begin{tabular}{l|l} 
hosp. \\
bronchiolitis
\end{tabular} & 1648281 & & $\begin{array}{l}\text { median length of hospital } \\
\text { stay }\end{array}$ & & $<5 y r s$ & $2-5$ days & 3 days & $\begin{array}{l}\text { Shay, D.K., Holman, R.C., Newman, R.D., Liu, LL.L., Stout, J.W. and Anderson, L.J., 1999. Bronchiolitis- } \\
\text { associated hospitalizations among US children, 1980-1996. Jama, 282(15), p. p.1440-1446. }\end{array}$ \\
\hline & observational & 1 year & $\begin{array}{l}\begin{array}{l}\text { otherwise } \\
\text { healthy ILI } \\
\text { children }\end{array} \\
\end{array}$ & 235 & & $\begin{array}{l}\text { median duration of } \\
\text { hospitalization }\end{array}$ & & \begin{tabular}{|l|l} 
6months -10 \\
yrs
\end{tabular} & & 6 days & 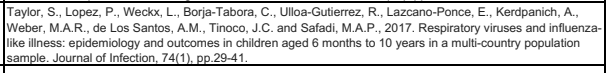 \\
\hline & observational & 2003-2006 & \begin{tabular}{|l|} 
children in Hong \\
Kong \\
hospitalized for \\
acaut respiratory \\
infection
\end{tabular} & & & $\begin{array}{l}\text { mean duration of } \\
\text { hospitalization }\end{array}$ & & $<18$ years & & 4.04 days & 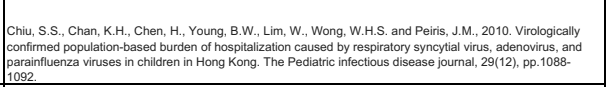 \\
\hline & observational & 2009-2011 & children $<5$ & 50 & NA & $\begin{array}{l}\text { median length of hospital } \\
\text { stay }\end{array}$ & & $<5$ & $3-5$ days & 4 days & 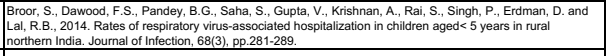 \\
\hline hospitalization & & & & & & & & & & & \\
\hline & observational & 2011-2012 & $\begin{array}{l}\begin{array}{l}\text { adults with } \\
\text { cardioulmonary } \\
\text { disease on } \\
\text { congestive heart } \\
\text { failure }\end{array}\end{array}$ & 445 & NA & $\begin{array}{l}\text { proportion hospitalized } \\
\text { during study }\end{array}$ & \begin{tabular}{|l|} 
excluded from \\
plot. study pop \\
has advanced \\
pulmonary \\
disease or \\
congestive heart \\
failure.
\end{tabular} & $>50$ & & 0.29 & 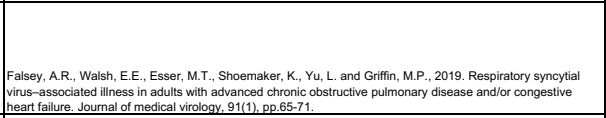 \\
\hline & observational & $1996-2000$ & $\begin{array}{l}3 \text { HMo } \\
\text { databases }\end{array}$ & & & $\begin{array}{l}\text { proportion hospitalized } \\
\text { per season }\end{array}$ & & all & & 0.062 & 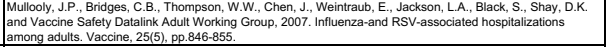 \\
\hline & observational & 2000-2001 & children ARI & 592 & NA & $\begin{array}{l}\text { proportion hospitalized } \\
\text { during study }\end{array}$ & & $<5$ & & 0.0035 & 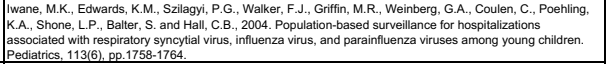 \\
\hline & observational & 2009-2011 & children $<5$ & 245 & NA & $\begin{array}{l}\text { proportion hospitalized } \\
\text { during study }\end{array}$ & & $<5$ & & 0.0035 & $\begin{array}{l}\text { Broor, S., Dawood, F.S., Pandey, B.G., Saha, S., Gupta, V., Krishnan, A., Rai, S., Singh, P., Erdman, D. and } \\
\text { Lal, R.B., 2014. Rates of respiratory yirus-associted hospitalization in children aged < } 5 \text { years in rural } \\
\text { northern India. Journal of Infection, 68(3), pp.281-289. }\end{array}$ \\
\hline & observational & $1989-2000$ & children $<2$ & 4618 & NA & $\begin{array}{l}\text { proportion hospitalized } \\
\text { per year during study }\end{array}$ & & $<2$ & & 0.02 & 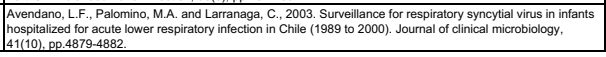 \\
\hline
\end{tabular}


medRxiv preprint doi: https://doi.org/10.1101/2020.02.04.20020404; this version posted April 23, 2021. The copyright holder for this preprint (which was not certified by peer review) is the author/funder, who has granted medRxiv a license to display the preprint in perpetuity.

\section{It is made available under a CC-BY-NC 4.0 International license.}

\begin{tabular}{|c|c|c|c|c|c|c|c|c|c|}
\hline & observational & 1 year & $\begin{array}{l}\begin{array}{l}\text { otherwise } \\
\text { healthy LII } \\
\text { children }\end{array} \\
\end{array}$ & 235 & $\begin{array}{l}\text { number hospitalized out } \\
\text { of } 235\end{array}$ & \begin{tabular}{|c|}
6 months-10 \\
yrs
\end{tabular} & & 0.021 & 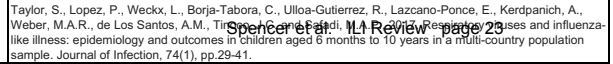 \\
\hline & observational & $<=1976$ & $\begin{array}{l}\text { hospitalized } \\
\text { jintants RSV }\end{array}$ & 23 & hospitalization proportion & infants & & 0.016 & $\begin{array}{l}\text { Weber, A., Weber, M. and Miligan, P., 2001. Modeling epidemics caused by respiratory syncytial virus (RSV). } \\
\text { Mathematical biosciences, 172(2), pp.95-113. }\end{array}$ \\
\hline \multirow{8}{*}{ case fatality rate } & & & & & & & & & \\
\hline & review & 1966-2009 & children & 36 studies & & $<=18 \mathrm{yrs}$ & & 0.165 & 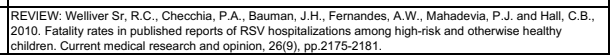 \\
\hline & observational & 1993-1995 & $\begin{array}{l}\text { hospitalized } \\
\text { children }\end{array}$ & 10767 & $\begin{array}{l}\text { nationally weighted \# } \\
\text { deaths/\# cases }\end{array}$ & & $0.004-0.0075$ & 0.0575 & $\begin{array}{l}\text { Howard, T.S. Hoffman, L..., Stang, P.E. and Simoes, E.A., 2000. Respiratory syncytial virus pneumonia in } \\
\text { the hospital setting: length of stay, charges, and mortality. The Journal of pediatrics, 137(2), pp.227-232. }\end{array}$ \\
\hline & observational & $2009-2013$ & all respiratory & $\begin{array}{l}4378 \\
\text { annually }\end{array}$ & deaths per person-year & all & & 0.00031 & 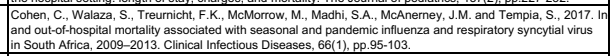 \\
\hline & observational & 2001-2003 & hosp. respiratory & 413 & deaths during study & $<5 \mathrm{yrs}$ & & 0.0015 & 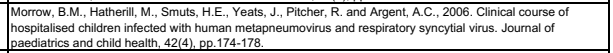 \\
\hline & observational & 2000 & $\begin{array}{l}\text { hosp. acute } \\
\text { bronchiolotis }\end{array}$ & 636 & deaths during study & $<1 \mathrm{yr}$ & & 0.007 & 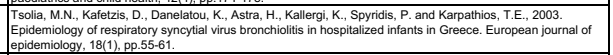 \\
\hline & observational & $1989-2000$ & $\begin{array}{l}\text { hosp. children }< \\
2\end{array}$ & 4618 & "Fatalily rate" & $<2 \mathrm{yrs}$ & & 0.001 & $\begin{array}{l}\text { Avendano, L.F., Palomino, M.A. and Larranaga, C., 2003. Surveillance for respiratory syncytial virus in infants } \\
\text { hospitalized for acute lower respiratory infection in Chile (1989 to 2000). Journal of clinical microbiology, } \\
\text { 411(10), pp.4879-4882. }\end{array}$ \\
\hline & review & before 2013 & & & "mortality" & $5 \mathrm{yls}$ & $.08-1$ & 0.09 & Lee, N., Qureshi, S.T., Other viral pneumonias. Crit Care Clin 29 (2013) 1045-1068 \\
\hline \multirow[t]{8}{*}{20} & & & & & & & & & \\
\hline & estimated & & & & & & $1.2-2.1$ & 1.65 & $\begin{array}{l}\text { Weber, A., Weber, M. and Milligan, P., 2001. Modeling epidemics caused by respiratory syncytial virus (RSV). } \\
\text { Mathematical biosciences, 172(2), pp.95-113. }\end{array}$ \\
\hline & estimated & & & & & & & 3 & 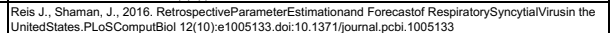 \\
\hline & estimated & 2003-2009 & & & & & $2.26-8.9$ & 4.6 & 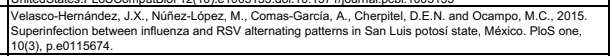 \\
\hline & estimated & & & & & & $1.2-2.1$ & 1.65 & 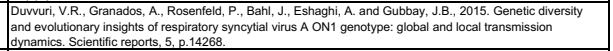 \\
\hline & estimated & $1989-2009$ & & & & & $8.9-9.1$ & 9 & 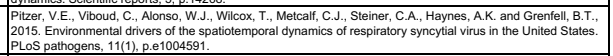 \\
\hline & estimated & 2018 & & & Ro at peak timing & & & 2.82 & $\begin{array}{l}\text { Reis, , and Shaman, } J, 2018 \text {. Simulation of four respiratory viruses and inference of epidemiological } \\
\text { parameters. Infectious Disease Modelling, 3, pp.23-34. }\end{array}$ \\
\hline & estimated & $2012-2017$ & & & average Ro & & & 1.6 & $\begin{array}{l}\text { Levy, N., Iv, M. and Yom-Tov, E., 2018. Modeling influenza-like illnesses through composite compartmental } \\
\text { models. Physica A: Statistical Mechanics and its Applications, 494, pp.288-293. }\end{array}$ \\
\hline
\end{tabular}


medRxiv preprint doi: https://doi.org/10.1101/2020.02.04.20020404; this version posted April 23, 2021. The copyright holder for this preprint (which was not certified by peer review) is the author/funder, who has granted medRxiv a license to display the preprint in perpetuity. It is made available under a CC-BY-NC 4.0 International license .

\begin{tabular}{|c|c|c|c|c|c|c|c|c|c|c|c|}
\hline \begin{tabular}{|l} 
parameter \\
incubation period
\end{tabular} & type of study & $\frac{\mid \text { study time }}{20001-2002}$ & population & $\begin{array}{l}\text { sample size } \\
102\end{array}$ & e- strain & definition of & 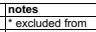 & 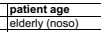 & $\begin{array}{l}\frac{I r a n g e}{1-30 \text { days }} \\
1\end{array}$ & $\begin{array}{lll}\text { mana } \\
\text { 15.5 days }\end{array}$ & 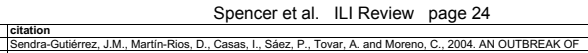 \\
\hline & systematic review & & & review & & & $\left|\begin{array}{c}\text { range and } \\
\text { centra tendency }\end{array}\right|$ & all & 4-8 days & 6 days & 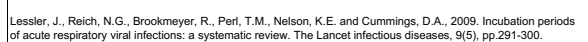 \\
\hline & $\begin{array}{l}\text { anedotalale } \\
\text { adenovirus }\end{array}$ & $\begin{array}{l}\text { July to Sept } \\
1996\end{array}$ & & 736 & |lobservationa & 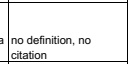 & & \begin{tabular}{|l} 
federal service \\
training academy
\end{tabular} & $6-9$ days & 7.5 days & 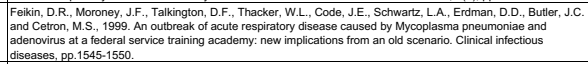 \\
\hline & experimental & 1945 & adult males & 5 & ARD & $\begin{array}{l}\text { inoculation to onset of } \\
\text { symptoms }\end{array}$ & \begin{tabular}{|l|l}
$A$ ARD assumed to \\
be adenovirus
\end{tabular} & adult & 5-6 days & 5.5 days & 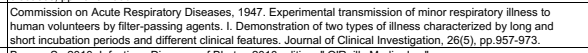 \\
\hline & textbook chapter & NA & & NA & & no deffitition & & & 4.12 days & 8 days & $\begin{array}{l}\text { Berger, S.. 2010. Infectious Diseases of Bhutan } 2010 \text { edition. "O'Reilly Media, Inc.". } \\
\text { Tanz, R.R. "Sore Throat", Kliegman, R.M., Lye, P.S., Bordini, B.J., Toth, H. and Basel, D., 2017. Nelson Pedia }\end{array}$ \\
\hline & reference chapter & $\mathrm{NA}$ & & NA & & no definition & & & $2-4$ days & 3 days & $\begin{array}{l}\text { Symptom-Based Diagnosis E-Book. Elseverier Heath Sciences. } \\
\text { Symprot, }\end{array}$ \\
\hline & review & before 2004 & literature & & & & & & 4.14 days & 9 days & 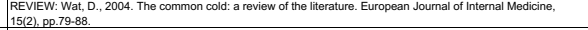 \\
\hline & textbook chapter & $\mathrm{NA}$ & & & & & lin textbook & & 2-14 days & 8 days & 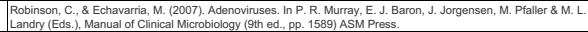 \\
\hline fiectious period & & & & & & & & & & & \\
\hline & observational & 2001-2002 & & 102 & & & & elderly (noso) & 17 days max & 9 days & 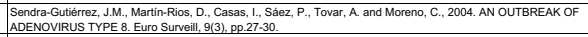 \\
\hline & observational & 1 year & $\begin{array}{l}\begin{array}{l}\text { ththerwise healthy ILI } \\
\text { children }\end{array} \\
\end{array}$ & 141 & seasonal & $\begin{array}{l}\text { mean duration of LI } \\
\text { episode }\end{array}$ & & $\begin{array}{l}6 \text { months-10 } \\
\text { years }\end{array}$ & & 9.2 days & 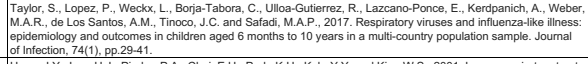 \\
\hline & observational & & $\begin{array}{l}\text { children positive for } \\
\text { adenovirus }\end{array}$ & 74 & & & & & & 10.6 days & 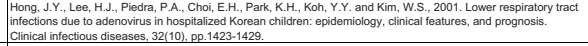 \\
\hline & textbook chapter & NA & adults & & & $\begin{array}{l}\text { viral shedding period } \\
\text { after recovery }\end{array}$ & & & up to 1 week & 4 days & 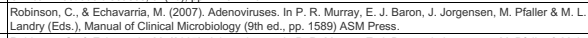 \\
\hline & textbook chapter & $\mathrm{NA}$ & children & & & $\begin{array}{l}\text { viral shedding period } \\
\text { following illess }\end{array}$ & $\mid \begin{array}{l}\text { excluded from } \\
\text { plot }\end{array}$ & & $3-6$ weeks & 31.5 days & 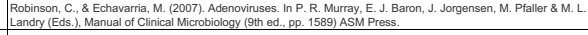 \\
\hline hospitalization perio & & & & & & & & & & & \\
\hline & observational & 1 year & 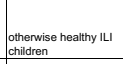 & 141 & seasonal & $\begin{array}{l}\begin{array}{l}\text { median duration of } \\
\text { hospitalization }\end{array} \\
\end{array}$ & & $\begin{array}{l}6 \text { months- } 10 \\
\text { years }\end{array}$ & & 4 days & 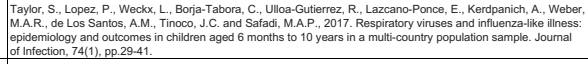 \\
\hline & observational & $2003-2006$ & $\begin{array}{l}\text { children in Hong Kong } \\
\text { hospitilized for acute } \\
\text { respiratory infection }\end{array}$ & & & $\begin{array}{l}\text { mean duration of } \\
\text { hospitalization }\end{array}$ & & $<18$ years & & 3.12 days & 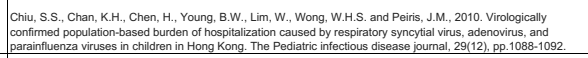 \\
\hline & observational & 2 years & $\begin{array}{l}\text { immunocompetent } \\
\text { children hospitaized } \\
\text { due to adenovirus }\end{array}$ & 78 & & $\begin{array}{l}\text { mean duration of } \\
\text { hospitalization }\end{array}$ & & $17 \pm 10$ months & & 7 days & 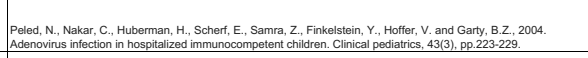 \\
\hline hospitalization rate & & & & & & & & & & & \\
\hline & & & & & & & & $\mid<18$ & & 0.418 & 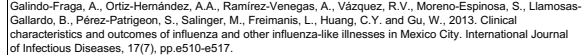 \\
\hline & & & & & & & & $18-59$ & & 0.667 & 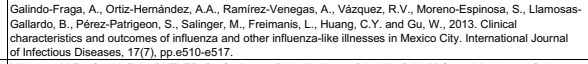 \\
\hline & observational & 1957 & military recruits & & & $\begin{array}{l}\text { percent hospitalized } \\
\text { oue to adenovirus in } 1 \\
\text { yr }\end{array}$ & & & & 0.1 & 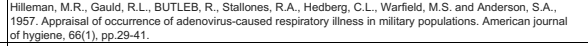 \\
\hline & observational & 1 year & $\begin{array}{l}\begin{array}{l}\text { otherwise healthy ILI } \\
\text { children }\end{array} \\
\end{array}$ & 141 & seasonal & percent hospitalized & & $\begin{array}{l}6 \text { months- } 10 \\
\text { years }\end{array}$ & & 0.014 & 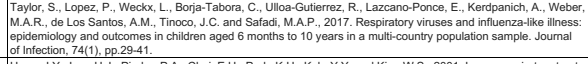 \\
\hline & observational & | 1990-1998 & \begin{tabular}{|l} 
conidren wl lower \\
respiratory tract \\
infection
\end{tabular} & & & \begin{tabular}{|l} 
percent of study \\
patients hospitalized
\end{tabular} & & & & 0.95 & 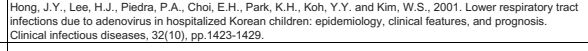 \\
\hline case fatality rate & & & & & & & & & & & \\
\hline & observational & & & & & & & 18-59 & & 0.067 & 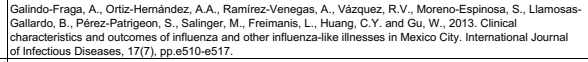 \\
\hline & observational & & $\begin{array}{l}\text { adenovirus infected } \\
\text { children }\end{array}$ & & & & $\begin{array}{l}\text { excluded drom } \\
\text { plot nosocomial }\end{array}$ & young children & & 0.67 & \begin{tabular}{|l} 
Westley, A.G., Pather, M. and Tait, D., 1993. Nosocomial adenovirus infection in a paediattic respiratatory unit. \\
Journal of Hospital Infection, 25(3), pp. 183-190.
\end{tabular} \\
\hline & observational & & $\begin{array}{l}\text { pediatric chronic care } \\
\text { residents }\end{array}$ & & & & & |children & & 0.16 & 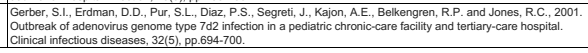 \\
\hline
\end{tabular}


medRxiv preprint doi: https://doi.org/10.1101/2020.02.04.20020404; this version posted April 23, 2021. The copyright holder for this preprint (which was not certified by peer review) is the author/funder, who has granted medRxiv a license to display the preprint in perpetuity.

\section{It is made available under a CC-BY-NC 4.0 International license .}

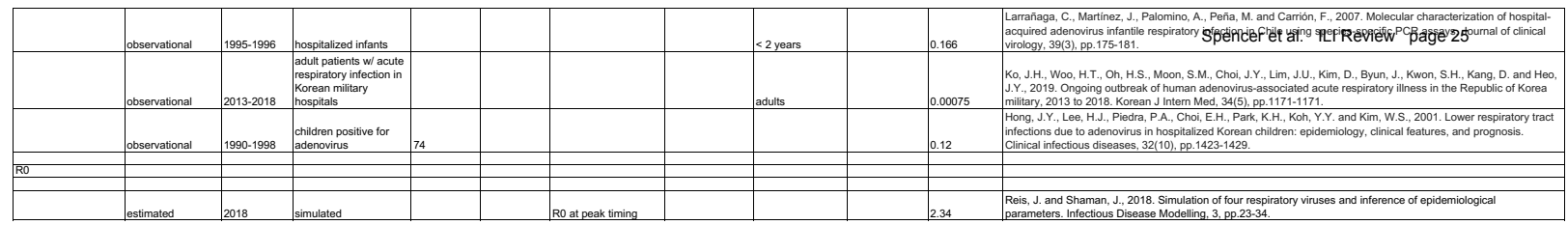


medRxiv preprint doi: https://doi.org/10.1101/2020.02.04.20020404; this version posted April 23, 2021. The copyright holder for this preprint (which was not certified by peer review) is the author/funder, who has granted medRxiv a license to display the preprint in perpetuity. It is made available under a CC-BY-NC 4.0 International license .

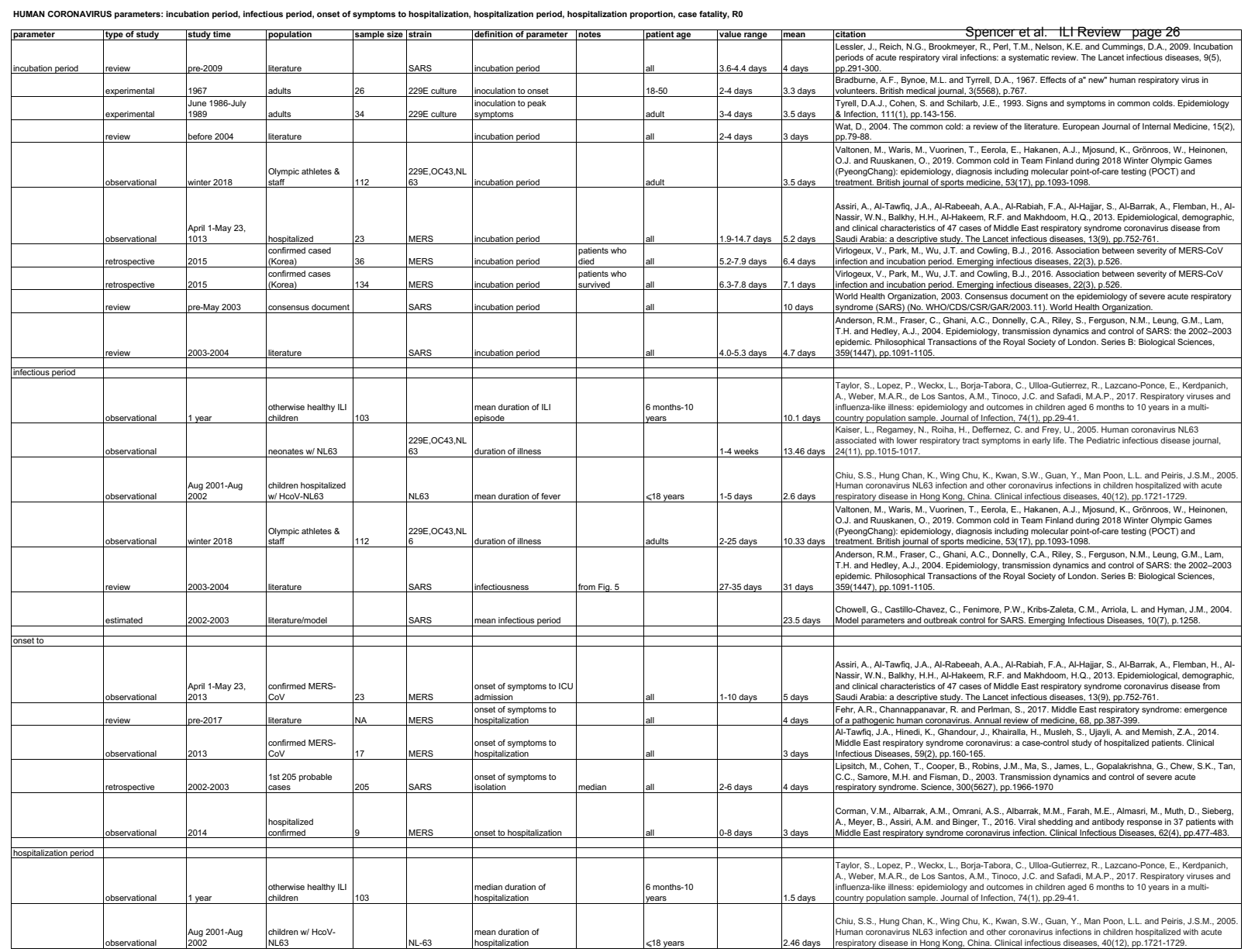


medRxiv preprint doi: https://doi.org/10.1101/2020.02.04.20020404; this version posted April 23, 2021. The copyright holder for this preprint (which was not certified by peer review) is the author/funder, who has granted medRxiv a license to display the preprint in perpetuity.

It is made available under a CC-BY-NC 4.0 International license .

\begin{tabular}{|c|c|c|c|c|c|c|c|c|c|c|}
\hline & observational & $2001-2003$ & $\begin{array}{l}\text { children w/ Hcov-NL } \\
\text { hospitalized for acute } \\
\text { respiritarort tract } \\
\text { infections }\end{array}$ & 12 & & $\begin{array}{l}\begin{array}{l}\text { mean duration of } \\
\text { hospitalization }\end{array} \\
\end{array}$ & $\leq 3$ years & & 4.9 days & 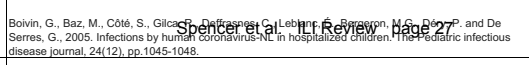 \\
\hline & observational & 2014 & $\begin{array}{l}\begin{array}{l}\text { hospitalized } \\
\text { confirmed }\end{array} \\
\text { con }\end{array}$ & 37 & MERS & $\begin{array}{l}\begin{array}{l}\text { average time of } \\
\text { hospitalization }\end{array} \\
\end{array}$ & all & & 11 days & 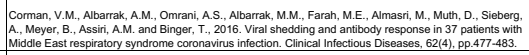 \\
\hline \multirow[t]{5}{*}{ hospitalazation } & & & & & & & & & & \\
\hline & observational & 1 year & $\begin{array}{l}\begin{array}{l}\text { otherwise healthy ILI } \\
\text { children }\end{array} \\
\end{array}$ & 103 & seasonal & percent hospitalized & $\begin{array}{l}6 \text { months- } 10 \\
\text { years }\end{array}$ & & 0.019 & 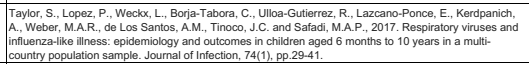 \\
\hline & observational & Jan-Mar 2002 & $\begin{array}{l}\text { Hcov-NL63 positive } \\
\text { patients }\end{array}$ & 19 & NL63 & percent hospitalized & $\begin{array}{l}1 \text { month-100 } \\
\text { years }\end{array}$ & & 0.21 & 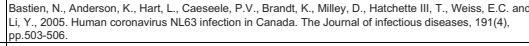 \\
\hline & observational & & $\begin{array}{l}\text { coronovavirus positive } \\
\text { patients w clinical } \\
\text { respiratory infection }\end{array}$ & 48 & & percent hospitalized & all & & 0.52 & 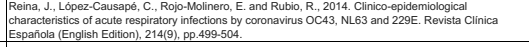 \\
\hline & observational & \begin{tabular}{|l} 
Aug 2001-Aug \\
2002
\end{tabular} & $\begin{array}{l}\text { children wi Hoov- } \\
\text { NL63 }\end{array}$ & & NL63 & percent hospitalized & s18 years & & 0.0022 & 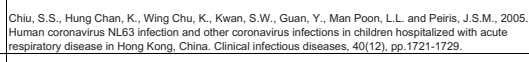 \\
\hline \multirow[t]{14}{*}{ case fatality } & & & & & & & & & & \\
\hline & review & & $\begin{array}{l}\text { confirmed MERS- } \\
\text { col cases }\end{array}$ & & MERS & case fatality rate & all & & 0.33 & 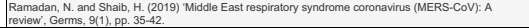 \\
\hline & retrospective & 2015 & $\begin{array}{l}\text { MERS-Cov South } \\
\text { Korea }\end{array}$ & 186 & MERS & case fatality rate & & & 0.19 & 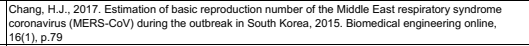 \\
\hline & observational & Jan-Mar 2002 & $\begin{array}{l}\text { Hcov-NL63 positive } \\
\text { children }\end{array}$ & 19 & NL63 & case fatality rate & & & 0.053 & 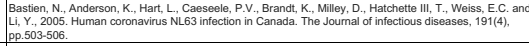 \\
\hline & observational & & 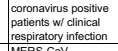 & 48 & & case fatality rate & all & & 0 & 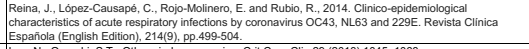 \\
\hline & observational & $1995-2000$ & \begin{tabular}{|l|} 
MERS-Cov \\
Hovi positive elderly \\
pationt wi enty \\
underlying \\
conditions
\end{tabular} & 5 & MERS & case fatality rate & $>65$ years & $6-16 \%$ & 0.11 & 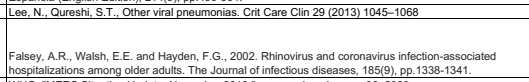 \\
\hline & retrospective & $2002-2019$ & confirmed cases & 2494 & MERS & case fatalily rate & all & & 0.344 & 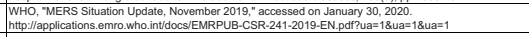 \\
\hline & estimated & & \begin{tabular}{|l} 
MERS-Cov Saudi \\
Arabia
\end{tabular} & & MERS & Ro & & & 4.5 & 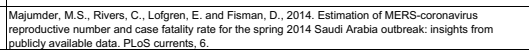 \\
\hline & estimated & 2015 & $\begin{array}{l}\text { MERS-Cov South } \\
\text { Korea }\end{array}$ & 186 & MERS & Ro & & & 8 & 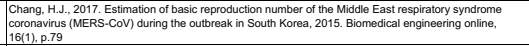 \\
\hline & estimated & & $\begin{array}{l}\text { SARS-Cov Hong } \\
\text { Kong }\end{array}$ & & SARS & Ro & & & 2.7 & 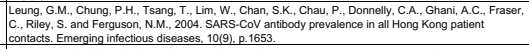 \\
\hline & $\begin{array}{l}\text { estimated } \\
\text { estimated }\end{array}$ & 2015 & \begin{tabular}{|l} 
MERS-Cov South \\
Korea \\
hCov
\end{tabular} & & MERS & $\frac{\mathrm{R} 0}{\mathrm{R} 0}$ & & $\begin{array}{l}0.1351 \text { or } \\
5.3973 \\
22.37\end{array}$ & $\frac{2.77}{2.95}$ & 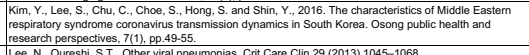 \\
\hline & estimated & $2002-2003$ & \begin{tabular}{|l} 
SARVS- \\
Singapore/Hong \\
Kong
\end{tabular} & 205 & SARS & Ro & & $2.2 \cdot 3.6$ & 22.95 & 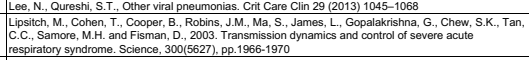 \\
\hline & review & $2002-2003$ & SARS (literature) & & SARS & Ro & & & 3 & 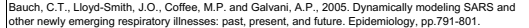 \\
\hline & $\begin{array}{l}\text { Irtorspectivelestima } \\
\text { ted }\end{array}$ & $2002-2003$ & SARS & 1512 & SARS & Ro & & & & 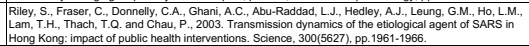 \\
\hline
\end{tabular}


medRxiv preprint doi: https://doi.org/10.1101/2020.02.04.20020404; this version posted April 23, 2021. The copyright holder for this preprint (which was not certified by peer review) is the author/funder, who has granted medRxiv a license to display the preprint in perpetuity.

It is made available under a CC-BY-NC 4.0 International license .

\begin{tabular}{|c|c|c|c|c|c|c|c|c|c|c|c|}
\hline & type of study & Istudy time & population & Sample size & Istrain & definition of parameter & notes & patient age range & value range & mean & Tcitation $\quad$ Spencer et al. ILI Review page 28 \\
\hline & Systematic review & before 2009 & Hereature & $\begin{array}{l}\begin{array}{l}\text { explobs } \\
\text { sucuies }\end{array} \\
\end{array}$ & & & trange and central tendency & & 2-4 days & 2 days & 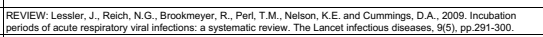 \\
\hline & review & before 2011 & Hiterature & & |citation network & & & & & & 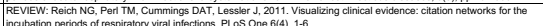 \\
\hline & experimental & 30 days & male prisoners & 13 & RVtype 15 & $\begin{array}{l}\text { linoculation to appearanco of } \\
\text { sympotoms }\end{array}$ & & adule & $2-4$ days & 3 days & 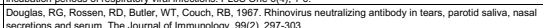 \\
\hline & experimental & 30 days & asthmatic subjects & 10 & 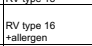 & $\begin{array}{l}\text { inoculation to appearanco of } \\
\text { symptoms }\end{array}$ & & 18055 & 1.5 .5 days & 2.5 days & 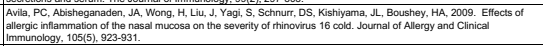 \\
\hline & experimental & 30 days & asthmatic subjects & 10 & RV type 16 & $\begin{array}{l}\text { inoculation to appearance of } \\
\text { symptoms }\end{array}$ & & 181055 & 1-1 days & 1 days & Avila e tal (above). \\
\hline & experimental & 5 days & healthy adults & 21 & RV type 23 & $\begin{array}{l}\text { insoculation to a appearances of } \\
\text { syymploms }\end{array}$ & & 18045 & 2-2days & 2 days & 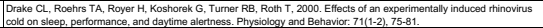 \\
\hline & experimental & 5 days & healthy adults & 27 & T.39 and HH & $\begin{array}{l}\text { insoculation to peak } \\
\text { syyplotis }\end{array}$ & & adult & 2.3 days & 2.5 days & 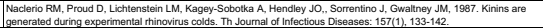 \\
\hline & experimental & 5 days & healthy adults & 18 & T.39 & $\begin{array}{l}\text { inincoulation nto appearances of } \\
\text { syymptoms }\end{array}$ & 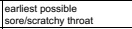 & adult & $0.42-0.67$ days & 0.55 days & 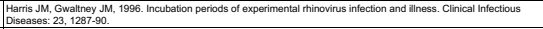 \\
\hline & experimental & 30 days & healthy adults & 20 & HRV & $\begin{array}{l}\text { incoculation to peak } \\
\text { symploms }\end{array}$ & & adult & 2-4 days & 3 days & 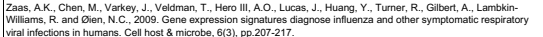 \\
\hline & experimental & 5 days & adults & 193 & RVg and RV14 & 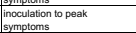 & & adult & $2-3$ days & 2.5 days & 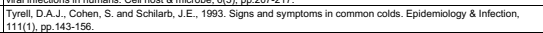 \\
\hline & review & betorere 2004 & Hitarture & & & & & & $2-7$ days & 4.5 days & 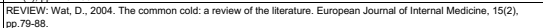 \\
\hline mectious peried & & & & & & & & & & & \\
\hline & observational & 1 year & $\begin{array}{l}\text { otherwise healthy ILI } \\
\text { children }\end{array}$ & 986 & & mean duration of ILI episode & & 6 months- 10 days & & 9.6 days & 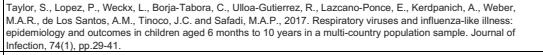 \\
\hline & observational & $\begin{array}{ll}\text { winiert 1992-3 } \\
\text { and 1993-4 }\end{array}$ & 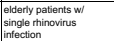 & 96 & & median duration of iliness & "excluded from plot & elderly & & 16 days & 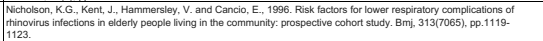 \\
\hline & observational & Sept-Oct 1994 & $\begin{array}{l}\text { HSV culture-positive } \\
\text { adults }\end{array}$ & & & $\begin{array}{l}\text { median duration of cold } \\
\text { episode }\end{array}$ & & adult & & 11 days & 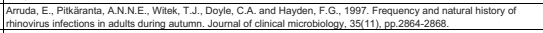 \\
\hline & experimental & & healthy adult males & 32 & 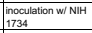 & viral shedding period & & adult & & 10 days & 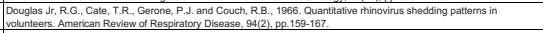 \\
\hline & textbook chapter & & & & & average length of symptoms & & all & & 7 days & 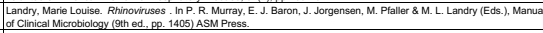 \\
\hline hospitalization period & & & & & & & & & & & \\
\hline & observational & iyear & \begin{tabular}{|l|l} 
otherwise healthy ILI \\
children
\end{tabular} & 986 & & $\begin{array}{l}\text { mestian duration of } \\
\text { hospitilization }\end{array}$ & & $\begin{array}{l}6 \text { months }-10 \\
\text { years }\end{array}$ & & 1.5 days & 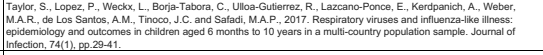 \\
\hline & retrospective & Jan 2014-Apr & hospitalized children & 198 & & $\begin{array}{l}\text { diffithtw. length of hospital } \\
\text { stat for HAV positive vs. no } \\
\text { respiratory virus }\end{array}$ & & children & & 0.4 days & 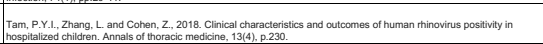 \\
\hline & observational & $2003-2005$ & 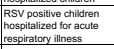 & 332 & & median length of stay & & $<5$ years & & 1.67 days & 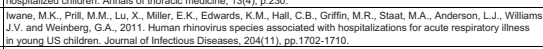 \\
\hline rospitalization proportion & & & & & & & & & & & \\
\hline & observational & 1 year & $\begin{array}{l}\text { otherwise healthy ILI } \\
\text { children }\end{array}$ & 986 & & percent hospitalized & & $\begin{array}{l}6 \text { months }-10 \\
\text { years }\end{array}$ & & 0.024 & 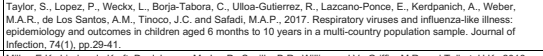 \\
\hline & observational & $2008-2010$ & 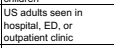 & & & \begin{tabular}{|l} 
Thinovius associated \\
hospitalization per year
\end{tabular} & & adult & & 0.003 & 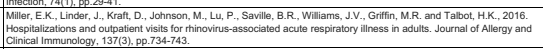 \\
\hline & observational & 1998-2001 & LL infants & & & $\begin{array}{l}\text { Percent hospitaizzed out of } \\
\text { infants with HRV }\end{array}$ & & infant & & 0.0093 & 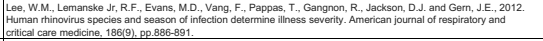 \\
\hline case fatality proportion & & & & & & & & & & & \\
\hline & & & \begin{tabular}{|l} 
elderly patients w/ \\
single RSV infection
\end{tabular} & 96 & & percent of patients who died & & elderly & & 0.0104 & 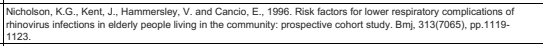 \\
\hline & thenting & a & 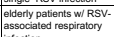 & 3 & & & & tats & & $0_{125}$ & 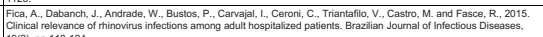 \\
\hline & observational & $1995-2000$ & $\begin{array}{l}\text { liffection } \\
\text { RSV positive elderly } \\
\text { patients w/ underlying } \\
\text { condtions }\end{array}$ & 32 & & percont of patients who died & & $>65$ years & & 0.125 & 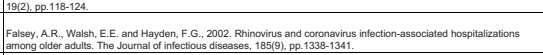 \\
\hline & lestimated & 2018 & simulated & & & Ro a peak timing & & & & 2 & Reis, J. and Shaman, J., 2018. Simulation of four respiritatory viruses and interencene of epidemiological parameters. \\
\hline & estimated & 2012-2017 & simulated & & & That peachiming & & & & 2.6 & 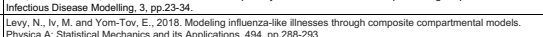 \\
\hline & 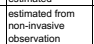 & & wild chimpanzees & & & average Ro & & & & & 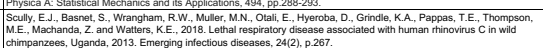 \\
\hline
\end{tabular}


medRxiv preprint doi: https://doi.org/10.1101/2020.02.04.20020404; this version posted April 23, 2021. The copyright holder for this preprint (which was not certified by peer review) is the author/funder, who has granted medRxiv a license to display the preprint in perpetuity.

It is made available under a CC-BY-NC 4.0 International license .

Spencer et al. ILI Review page 29

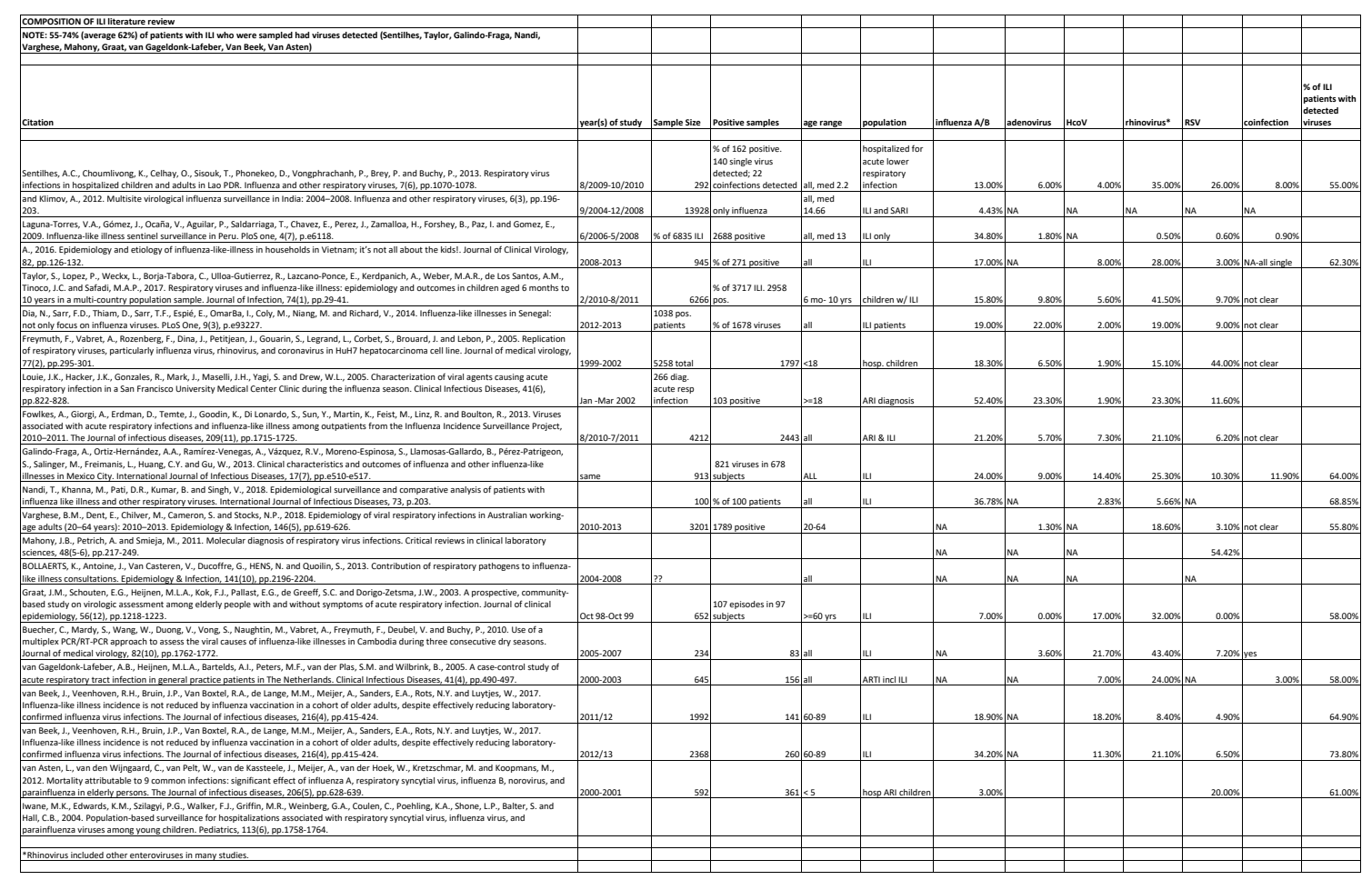

